\title{
THE EXTRABASINAL ELEMENTS IN LOWER PENNSYLVANIAN FLORAS OF THE MARITIME PROVINCES, CANADA: DESCRIPTION OF Adiantites, Pseudadiantites AND Rhacopteridium
}

Robert H. WAGNER

Jardín Botánico de Córdoba, Avenida de Linneo, s/n, 14004 Córdoba (Spain)

\begin{abstract}
Wagner, R.H., 2001. The extrabasinal elements in lower Pennsylvanian floras of the Maritime Provinces, Canada: description of Adiantites, Pseudadiantites and Rhacopteridium. [Los elementos extraconcales en las floras del Pensilvánico inferior de las provincias atlánticas de Canadá: descripción de Adiantites, Pseudadiantites y Rhacopteridium.] Revista Española de Paleontología, 16(2), 187-207. ISSN 0213-6937.
\end{abstract}

\begin{abstract}
Adiantites adiantoides (Lindley and Hutton) Kidston, Pseudadiantites sessilis (Roehl) Gothan and Pseudadiantites rhomboideus (Ettingshausen) comb. nov. are figured and described as well as Rhacopteridium speciosum (Ettingshausen) Hirmer, as part of a revision of lower Pennsylvanian floras of Nova Scotia. These species show a foliar branching structure which is described as "pseudopinnate" as against the fully planated pinnate structure of the Palaeozoic fern and pteridosperm fronds. Their systematic affinity is unknown. A discussion is presented of the genera Adiantites, Pseudadiantites, Aneimites, Palaeopteridium, and Triphyllopteris, and the problematic nature of the history of Adiantites is emphasised. The four species described are rare though rather more widespread than previous records suggested. Their occurrence is apparently linked to habitat and local palaeogeography rather than to considerations of general palaeogeographic distribution.
\end{abstract}

Keywords: Flora, Pennsylvanian, Namurian, Westphalian, Nova Scotia, extrabasinal.

\section{RESUMEN}

Se describen y figuran las especies Adiantites adiantoides (Lindley y Hutton) Kidston, Pseudadiantites sessilis (Roehl) Gothan, Ps. romboideus (Ettingshausen) comb. nov. y Rhacopteridium speciosum (Ettingshausen) Hirmer como parte de una revisión de las floras del Pensilvánico inferior de Nueva Escocia, Canadá. Estas especies muestran una estructura foliar "pseudopinnada" que no corresponde a la pinnatífida aplanada de las frondes de los helechos y pteridospermas del Paleozoico. Sus afinidades sistemáticas son desconocidas. Se presenta una discusión sobre la historia y el contenido de los géneros Adiantites, Pseudadiantites, Aneimites, Palaeopteridium y Triphyllopteris, haciendo hincapié en los cambios de definición del género Adiantites, que se presenta como el más problemático. Las cuatro especies descritas son raras, aunque no tan acantonadas geográficamente como algunos autores han indicado. Sus registros, más bien esporádicos, parecen estar relacionados con elementos de la paleogeografía local y pueden ser interpretados en clave de tratarse de especies foráneas a las facies pantanosas habituales en los ambientes hulleros del Pensilvánico.

Palabras clave: Flora, Pensilvánico, Namuriense, Westfaliense, Nueva Escocia, hábitat extraconcal.

\section{INTRODUCTION}

A small number of monographic papers dealing with megafloral taxa from lower Pennsylvanian strata of Atlantic Canada include Marie Stopes's (1914) excellent revision of the "Fern Ledges" flora of New Brunswick, originally described by Dawson $(1861,1862,1871,1873$, 1882) and Matthew (1906). Although Stopes showed clearly the similarity of this flora with contemporaneous
Carboniferous floras in western Europe, and proposed several synonymies, little notice was taken of her work by European authors, who generally acknowledged its quality but largely ignored its taxonomic consequences. A more comprehensive account of the lower Pennsylvanian floras of Maritime Canada, based on a description of megafloral remains from Nova Scotia, was published thirty years later by Bell (1944), who distinguished between a Riversdale Group and a 
Cumberland Group, which were assigned Westphalian A (presently Langsettian) and early Westphalian B (presently Duckmantian) ages, respectively. These two groups would be separated by a disconformity, implying the presence of a stratigraphic gap. Criticism of Bell's Riversdale Group and its applicability over the wide area which he envisaged, was first expressed by Belt (1964). In the most recent synthesis of the Carboniferous in Nova Scotia (Calder, 1998), the Cumberland Group is taken to incorporate the Riversdale, and Bell's disconformity and stratigraphic gap are regarded as non-existent. A revision of Bell's Riversdale and Cumberland floras, which is in progress, confirms this point of view. There is also an increased awareness that the Carboniferous of Maritime Canada comprises a number of different basins that possibly interconnected at some times, but which were bounded by upstanding relief during at least part of their existence. Ongoing sedimentological work provides evidence of basin margins (op. cit.). The higher ground is likely to provide a source of plant remains which reflect a non-coal-measure habitat corresponding to better drained soils. Fossil taxa corresponding to these so-called "extrabasinal" elements (Havlena, 1970) are described in the present paper.

Bell's (1944) memoir is more than half a century old and in view of the doubts about his stratigraphic conclusions, a critical revision of the fossil taxa on which he based at least part of these conclusions is overdue. The Geological Survey of Canada commissioned the present writer to prepare such a revision, and this is being done on the basis of a reexamination of the actual specimens figured and described by Bell (1944, 1966), and additional material in the collections of the Geological Survey in Ottawa. This study is made in the Botanical Garden of Córdoba, Spain, where material for comparison and the relevant palaeobotanical literature are available. As a result of this revision, which is in progress, at least twelve of the 20 taxa introduced by Bell as new, specifically different elements of the lower Westphalian floras of Maritime Canada are now recognised as previously described West European species, thus emphasising even more clearly the essential unity of eastern Canada with western Europe in Pennsylvanian times. Although some of the material is fragmentary, imposing limitations to the proper identification of certain taxa, around 90 different species can be recognised. This cannot be regarded as a full representation of the fossil flora that may be present in the lower Pennsylvanian of Nova Scotia (c. 120-130 species might be expected), but it does provide a reasonable basis for comparison. One of the more striking results of the revision has been the recognition of a number of taxa belonging to Adiantites, Pseudadiantites, Rhacopteridium, and Megalopteris. These are elements which are generally regarded as extrabasinal (sensu Havlena, 1970), meaning plants that lived on better drained soils and not in the mires that constituted the habitat of most of the coal-measure plants. Adiantites adiantoides (Lindley and Hutton) Kidston, $P$ seudadiantites rhomboideus (Ettingshausen), and $P$. sessilis (Roehl) are figured and described in the present paper, as well as Rhacopteridium speciosum (Ettingshausen).

\section{THE GENERA ADIANTITES, PSEUDADIANTITES, ANEIMITES, PALAEOPTERIDIUM, AND TRIPHYLLOPTERIS: A DISCUSSION}

Adiantites was introduced by Göppert (1836, p. 173) with the following diagnosis: "Frons stipitata, flabellatosemiorbiculata, integra, inciso-lobata aut pinnata. Pinnae suborbiculatae vel oblongae basi saepissime inaequales et cordatae, nervis creberrimis ab ima basi flabellatis dichotomis pluries furcatis aequalibus nervoque medio haud distincto." According to Göppert (1836, p. 216) this genus incorporated the neuropterids, whilst the first species quoted by Göppert is Adiantites digitatus, i.e. Ginkgo digitata (Brongniart) Heer from the Jurassic of Yorkshire, England. Schimper (1869, p. 424), who changed the name to Adiantides, maintained Göppert's criterium that the neuropterids were involved. Lesquereux (1880, p. 297), who credited Adiantites to Brongniart (presumably a slip of the pen), diagnosed Adiantites as follows: "Fronds large, bipinnate; pinnules oblique, simple or bi, trilobed, gradually narrowed to the point of attachment; veins dichotomous from the base, dividing fan-like, straight, thin, distinctly marked." $\mathrm{He}$ also referred Triphyllopteris Schimper and Archaeopteris Dawson to the group of Adiantites, meaning, quite probably, that he regarded Adiantites as subdivided into Triphyllopteris and Archaeopteris, both genera with folioles possessing a fan-shaped venation. In Potonié's "Lehrbuch" ( $2^{\text {nd }}$ edition, 1921, modified by W. Gothan, p. 78), the genus Adiantites Göppert pro parte (synonymised with Aneimites Dawson, 1860) is stated as being applied mainly to Kulm species (i.e. taxa of Mississippian age), with only a few species from the Coal Measures. Reference was made in the "Lehrbuch" to Aneimites fertilis White, and this was taken as proof that Adiantites would be a pteridosperm. This is not a foregone conclusion, however. Potonié-Gothan (1921) also mentioned that Adiantites sessilis (Röhl) Potonié and "Asplenites" reussii Ettingshausen should not be regarded as belonging to Adiantites. Reference was made also to Triphyllopteris Schimper, in regard to Triphyllopteris rhomboidea (Ettingshausen) Schimper. These considerations involved already four genera, amongst which Adiantites appeared as being the most problematical. (See also comments to this effect by Stopes, 1914, p. 55-56.) In fact, it took the redefinition of Adiantites in emended form by Kidston (1923, p. 186) for this genus to become more closely circumscribed. Kidston (1923, p. 186-187), gave the following diagnosis: "Frond tripinnate or quadripinnate, of lax growth, rachises of various degrees slender. Pinnae alternate, broadly lanceolate to oblong. Pinnules alternate, obovate, cuneate or wedge-shaped, rounded or truncate at apex and contracted at base into a longer or 
shorter footstalk. The upper pinnules are sometimes sessile and attached by a narrow base. The veins radiate from the base in a fan-like manner, undergo repeated dichotomies, and are of equal strength. Fuctification unknown." Göppert's original definition had clearly fallen by the wayside. Kidston (1923, p. 187) apparently accepted Gothan's point of view by mentioning that Aneimites (Wardia) fertilis (White, 1905) looked like Adiantites, and had small, pedicellate, oval-winged "seeds" attached. Although Kidston (1923) made no comparison with Triphyllopteris, this genus was included later (Kidston, 1924, p. 413) in the synonymy of Aneimites. On the other hand, he now distinguished Aneimites from Adiantites by referring to different frond structures and to a larger variation in pinnule size for Aneimites, the pinnules of which also seemed to obtain larger sizes. However, he did acknowledge the great similarity in pinnule shape and venation in Adiantites (as emended by Kidston, 1923) and Aneimites. He also mentioned that "when specimens of Aneimites are examined, they possess a recognisable character which is difficult to describe verbally." Evidently, these two genera remained difficult to distinguish from each other. Additionally, Kidston (1924, p. 414) accepted Aneimites as the senior synonym of Triphyllopteris because Schimper (1869), when he introduced the latter, included Aneimites acadicus Dawson in Triphyllopteris. Since Schimper's genus is based on Triphyllopteris collombiana Schimper, Kidston's argument is open to question. It is not intended to discuss Triphyllopteris at any length here. Suffice it to refer to the recent treatment of this genus and its type species by Knaus (1994).

It may be argued that Adiantites as emended by Kidston (1923) and Aneimites Dawson (1860) are perhaps not sufficiently different to warrant generic distinction. The most apparent problem is that Adiantites as a generic concept has suffered so many vicissitudes, and that Adiantites sensu Kidston, which coincides apparently with Potonié and Gothan's concept of this genus, is not at all what Göppert originally meant. Stopes (1914) was undoubtedly right in declaring Adiantites (Adiantides) an unsatisfactory genus. The matter was further complicated by Gothan (1929), when he separated Pseudadiantites sessilis (Röhl) from Adiantites. This puts automatically into question the attribution of Adiantites wardii Kidston from the Westphalian of England, a species which is regarded here as synonymous with Pseudadiantites rhomboideus (Ettingshausen) comb. nov. Ettingshausen's species was referred to Triphyllopteris rhomboidea (Ettingshausen) Schimper by Potonié and Gothan (1921), a generic attribution which was maintained by Nĕmejc (1928), but rejected by Knaus (1994), probably correctly.

A special genus, Palaeopteridium, was introduced by Kidston (1923, p. 201) to accommodate Asplenites reussii Ettingshausen. He gave the following diagnosis (loc. cit.): "Frond bipinnate, rachis stout, pinnae alternate. Pinnules very oblique to rachis, obovate, rounded above and contracted at base into a thick decurrent footstalk; upper margin bearing sharp-pointed, more or less strongly developed spine-like teeth. A single vein enters the pinnules, which, through repeated dichotomy, gives rise to a series of radiating veins of equal strength. Fructification unknown". Kidston distinguished Palaeopteridium from Adiantites Göppert emend. Kidston by noting that the latter possesses a more leathery texture of pinnules, which are also more oblique to the rachis, and have thick decurrent footstalks. The generic diagnosis of Palaeopteridium seems tailor-made for its type species, $P$. reussii (Ettingshausen). The differences noted with regard to Adiantites are relatively minor, however. On the other hand, Palaeopteridium reussii (Ettingshausen) was found to be consistently associated with the Noeggerathialean strobilus Lacoea (Leary, 1974, Leary and Pfefferkorn, 1977), a possible synonym of Discinites (see Nĕmejc, 1937). There is no evidence to link Adiantites sensu Kidston to the Noeggerathialeans. The species Pseudadiantites sessilis (Roehl) Gothan was transferred to Palaeopteridium by Leggewie (1966), who thus placed Pseudadiantites in synonymy with Palaeopteridium. This synonymy is perhaps not as well founded as would be desirable. The genus Pseudadiantites had been introduced by Gothan (1929, p. 19) as being separate from Adiantites on the basis of a midrib being present in the folioles, whereas Adiantites would have a fan-shaped venation without midrib. Gothan did not provide a proper diagnosis of Pseudadiantites, but stated that this genus, as defined on the species Pseudadiantites sessilis, was characterised by lateral pinnae with almost parallel margins (as in Palaeopteridium), the presence of small aphleboid folioles and ultimate foliar elements shaped like Sphenopteris or Neuropteris pinnules. Gothan (1929, p. 18) compared with Palaeopteridium reussii, but mentioned the denticulate margin of folioles and the presence of aphleboid elements in $P$. reussii as distinguishing characters. Leggewie (1966) accepted the distinction between Adiantites and Pseudadiantites, but regarded the latter as morphologically identical with Palaeopteridium. However, this begs the question as to whether Pseudadiantites sessilis (and similar species) should be regarded as Noeggerathialean. This is by no means certain. Perhaps, the most prudent approach is to leave Palaeopteridium reussii (Ettingshausen) Kidston on its own as a probable Noeggerathialean, and to keep Pseudadiantites sessilis and comparable species as a separate group, not necessarily attributable to the Noeggerathiales, although morphologically similar. In both cases branching systems on the archaeopterid (progymnosperm) pattern are present, rather than fully planated frond structures. Palaeopteridium reussii (Ettingshausen) Kidston is a rather special form with denticulate folioles arranged in alternate position on opposite sides of slender secondary axes, and large aphleboid, pinnate elements at the base of secondary axes and in the lower part of the plant. This development is rather special and not matched by Pseudadiantites sessilis and similar species. The best illustrations of Palaeopteridium reussii are in Kidston, 1923, pl. LV. It is noted that the specimens figured and described by 
Nĕmejc (1928, p. 79-80, Tab. IX, figs 5-7) as Palaeopteridium macrophyllum Nĕmejc seem to fall within the range of variation of Palaeopteridium reussii. This would have left the genus restricted to a single species, if Álvarez-Vázquez (1995) had not assigned Eremopteris michiganensis Arnold to Palaeopteridium. This is clearly a different species.

Leggewie's (1966) attribution of Pseudoadiantites sessilis (Röhl) Gothan to Palaeopteridium is thus regarded as questionable. Although the general organisation is similar, there is no hint of special aphleboid elements, and the folioles are ovate to obovate, entire, with rare lobation of anadromous leaflets. There is no record of associated fertile structures, such as have been recorded for Palaeopteridium reussii (Ettingshausen) Kidston, which Leary and Pfefferkorn (1977) assign, albeit tentatively, to the Noeggerathiales.

Similar to Pseudadiantites sessilis are Pseudadiantites rhomboideus (Ettingshausen) comb. nov. and "Adiantites" wardii Kidston which is regarded here as a synonym of Ps. rhomboideus. It also appears that Sphenopteris licens Bell may be referred to Pseudadiantites, probably as a synonym of Pseudadiantites sessilis. Summarising, it is proposed here to accept the genus Adiantites as emended by Kidston (1923), even though this does not conform to the original usage of this genus, to restrict Palaeopteridium to its type species, $P$. reussii (Ettingshausen) Kidston, and to $P$. michiganense (Arnold) Álvarez-Vázquez, and to reinstate Pseudadiantites for its type species, Ps. sessilis (Röhl) Gothan, applying this generic name also to Pseudadiantites rhomboideus (Ettingshausen) comb. nov. Although the distinction between Adiantites and Pseudadiantites on the basis of an absence or presence of a (poorly developed) midrib (Gothan, 1929) is rather unsatisfactory, this distinction is maintained here for Adiantites adiantoides (Lindley and Hutton) Kidston. Undoubtedly, these genera will have to be more critically examined in the future.

\section{SYSTEMATIC DESCRIPTIONS}

\author{
Genus Adiantites emend. Kidston 1923
}

\section{Diagnosis}

Branching systems with stalked, entire folioles which appear to be partly overlapping and not inserted in a single plane.

\section{Adiantites adiantoides (Lindley and Hutton) Kidston \\ Figs 1, 5a}

* 1834 Sphenopteris adiantoides Lindley and Hutton, p. 91, pl. CXV.
* 1923 Adiantites adiantoides (Lindley and Hutton) Kidston, p. 190-191 (including synonymy), pl. XLV, figs 3-4, pl. XLVI, figs 1,1a (photographic reproduction of holotype), fig. 2 .

1944 Adiantites adiantoides (Lindley and Hutton); Bell, p. 56, pl. II, fig. 1, pl. XIII, fig. 4.

1944 Sphenopteris lineata Bell pars, pl. VII, fig. 4.

1966 Adiantites adiantoides (Lindley and Hutton); Bell, pl. X, fig. 2 (after Bell, 1944, pl. II, fig. 1).

1966 Sphenopteris lineata Bell pars, pl. III, fig. 7.

* denotes types.

\section{Diagnosis}

Slender, rounded axes with partially overlapping, alternating, stalked, entire folioles with a rounded apex and a fan-shaped nervation without apparent midrib.

\section{Discussion}

The holotype of this species, from the Duckmantian of Durham County, northern England, was refigured photographically by Kidston (1923). The thin axes with partially overlapping, stalked folioles are clearly shown in this tripinnate specimen. Folioles are only a little longer than they are wide, and have broadly rounded apices. They appear entire, without lobation. Two additional specimens figured by Kidston (1923, pl. XLV, figs 3-4, pl. XLVI, fig. 2), from either Kinderscoutian to Yeadonian or lower Langsettian strata in Stirlingshire, Midland Valley of Scotland, are more fragmentary, but show the same kind of folioles.

Bell (1944) figured two specimens from locality 1063 , East Brook, tributary of Maccan River, North of East Southampton Station, Nova Scotia, Malagash Formation, which conform to the type. The specimen refigured by Bell (1966) is partially reproduced again (x 3) in the present paper (Fig. 1). Bell (1944, pl. VII, fig. 4; 1966, pl. III, fig. 7) also figured two specimens from loc. 879 , Oxford Junction, on River Philip south of Racetrack Brook, Nova Scotia, Boss Point Formation, under the name of Sphenopteris lineata Bell. These specimens are attributed to Adiantites adiantoides in the present paper. The holotype of Sphenopteris lineata Bell is referred to Pseudadiantites rhomboideus (Ettingshausen) by the present writer, and it is this species which appears most similar to A. adiantoides. However, as Kidston (1923, p. 191) observed, "Adiantites" rhomboideus has obovate folioles with more acute apices, as against the more wedge-shaped, rounded folioles of Adiantites adiantoides. The specimens from loc. 879 show folioles which tend to be trilobate in some places, and this invites comparison with the specimen figured by Nĕmejc (1928, pl. X, fig. 2) as Triphyllopteris rhomboidea (= Pseudadiantites rhomboideus). However, the more rounded apex of folioles in the specimens from Nova Scotia, and the absence of a midrib, set these specimens

Figure 1. Adiantites adiantoides (Lindley and Hutton) Kidston, x 3. Loc. 1063, Malagash Formation, Athol Syncline, north of East Southampton station, East Brook, tributary of Maccan River, Nova Scotia. GSC 9435. Previously figured by Bell, 1944, pl. II, fig. 1, and Bell, 1966, pl. X, fig. 2. 


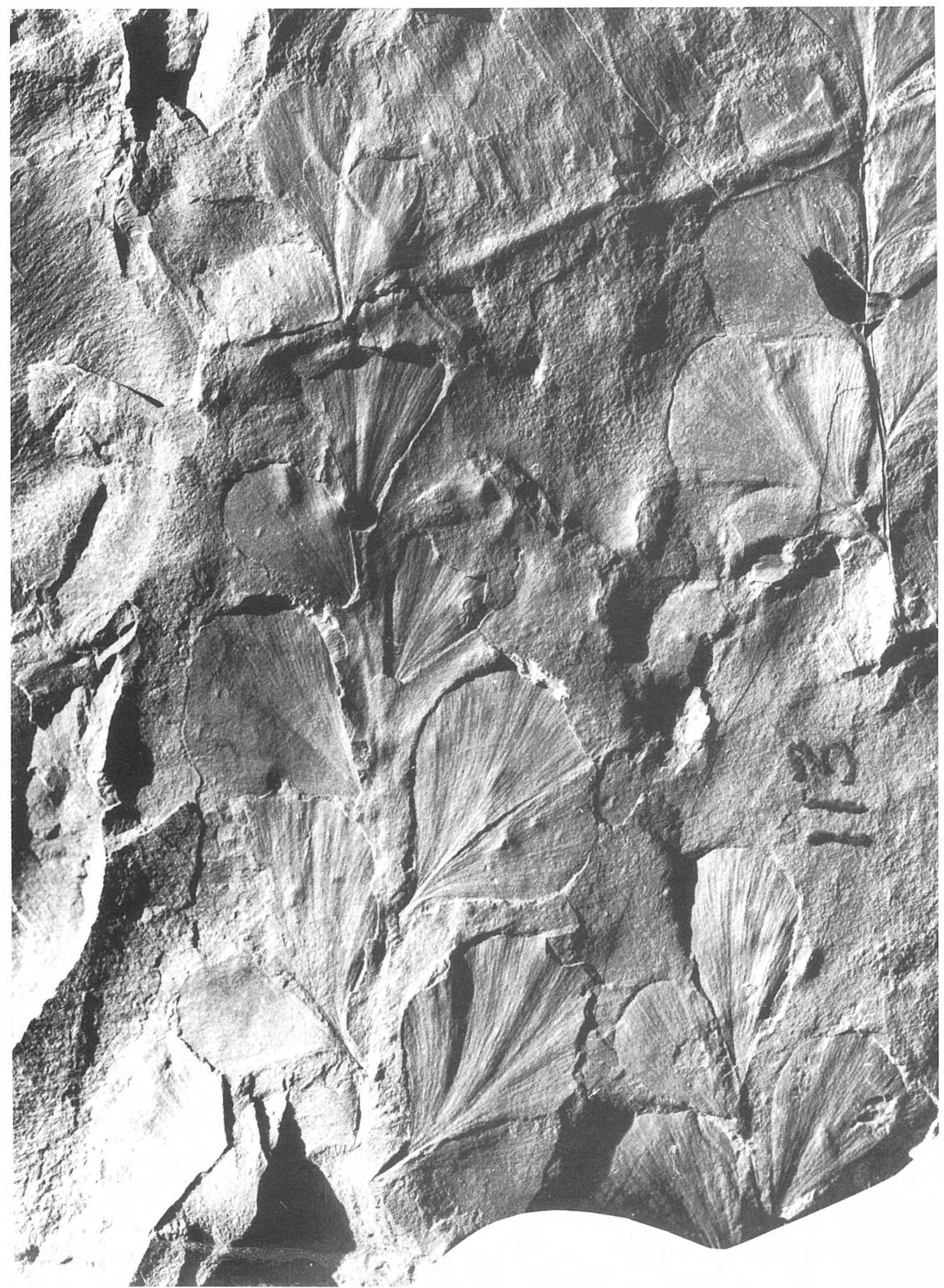


apart from Pseudadiantites rhomboideus. This leaves the vexed question of the generic attribution of Lindley and Hutton's species to either Adiantites as emended by Kidston (1923) or Pseudadiantites. Whereas the latter would possess folioles showing (a weakly expressed) midrib, Adiantites would be characterised by a fanshaped venation. Judging by this criterion, the proper attribution should be to Adiantites. The unsatisfactory nature of these genera has been pointed out already, and the absence of reproductive structures makes the distinction also subject to caution.

Occurrence: Kinderscoutian? to Yeadonian and Langsettian (also lower Duckmantian?) of British Isles and Maritime Provinces of Canada.

Canadian specimens assigned to A. adiantoides: GSC 9139, 9435. Locality 1063 (East Brook, tributary of Maccan River, north of East Southampton Station, Athol Syncline, Nova Scotia, Malagash Formation). GSC 5946, 5950. Locality 879 (River Philip, south of the mouth of Racetrack Brook, Oxford Junction, Tatamagouche Syncline, Nova Scotia, Boss Point Formation).

\section{Genus Pseudadiantites Gothan 1929}

\section{Diagnosis}

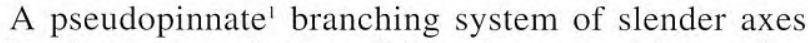
with subopposite, alternate foliar elements, either entire, lobate, or even pinnate, with a fan-shaped vein pattern, either with or without a midrib depending on the position, size and amount of pinnate division of the foliar elements.

'The term pseudopinnate is used here to convey the sense of an apparently pinnate frond structure which is not planated but consisting of axes on which folioles are inserted at an angle. These folioles are either entire, lobate, or even (rarely) pinnate.

\section{Pseudadiantites sessilis (Roehl) Gothan} Figs 2, 3d-e

*1868 Cyclopteris oblongifolia Göppert var. sessilis von Roehl, p. 45, Taf. XVI, figs 1, 1a.

1896 Adiantites sessilis (v. Roehl) Potonié, p. 19, fig. 2.

1921 “Adiantites” sessilis v. Roehl; Potonié-Gothan, p. 79, fig. 73 (same drawing as in Potonié, 1896, fig. 2).
1923 cf.Adiantites sessilis Potonié; Kidston, p. 196-197, pl. XLIII, figs 3, 3a-b.

1928 Adiantites sessilis v. Roehl; Jongmans, p. 15, pl. 3, fig. 2 (poorly figured specimen which has been accepted by Gothan, 1929, p. 18).

1929 Pseudadiantites sessilis (v. Roehl) Gothan, p. 17, Taf. 14, figs 1, 1a (same specimen as in Potonié, 1896).

* 1944 Sphenopteris licens Bell, p. 69, pl. XVI, figs 3-4, pl. XVII, figs 2-3, 5, pl. LIX, fig. 1.

1952-53Pseudadiantites sessilis (v. Roehl) Gothan; Stockmans et Willière, p. 223-224, pl. XLIV, figs 3, 3a.

*1953 Imparipteris (Neuropteris) flabellinervis Gothan, p. 59, Taf. 9, figs 2-3, Taf. 28, fig. 2, Taf. 30, fig. 6.

1957 Neuropteris flabellinervis Gothan; Fiebig, p. 17, Taf. II, fig. 1.

1957 Neuropteris flabellinervis Gothan; Rabitz, Taf. 16, fig. 8, Taf. 17, fig. 1.

1962 Neuropteris flabellinervis Gothan; Josten, p. 764, Taf. 3, fig. 4.

1966 Palaeopteridium sessilis (Potonié) Leggewie, p. 299-300, Taf. 1, fig. 2, Taf. 2, figs 1-3, Taf. 3, figs 1, 1a, Taf. 4, figs 1, 1a (same specimen as in Potonié, 1896, fig. 2); non Taf. 1, fig. 1 (= Neuropteris (Imparipteris) heterophylla Brongniart of Gothan, 1953, Taf. 1, figs 1, 1a - attributed to Neuropteris loshii Brongniart by Laveine, 1967, p. 145).

1966 Adiantites oblongifolius Göppert; Bell, pl. IV, figs $5,8,10$.

1977 Palaeopteridium sessilis (Potonié) Leggewie; Remy und Remy, p. 187, Bild 76a-d (same specimen as in Gothan, 1953, Taf. 28, fig. 2 - as Neuropteris flabellinervis -, and in Leggewie, 1966, Taf. 1, fig. 2).

1983 Pseudadiantites sessilis (Röhl) Gothan; Josten, p. 89, Taf. 28, figs 2, 2a; Abb. 53.

1991 Palaeopteridium sessilis (Potonié) Leggewie; Josten, p. 191, Taf. 78; Abb. 111.

1995 Palaeopteridium sessilis (Potonié) Leggewie; Álvarez-Vázquez, p. 131-132, lám. 44, fig. 6.

\section{Diagnosis}

Pseudopinnate foliar structures consisting of slender axes with alternate branches on which stalked ovate folioles are inserted alternately and apparently in subopposite position. Terminal folioles are relatively large and similar to lateral elements. Folioles either partly overlapping or widely apart, of rather small size, c. 3-5 $\mathrm{mm}$ long. Venation fan-shaped, with a poorly developed

Figure 2. Pseudadiantites sessilis (Roehl) Gothan, x 3. a-b. Loc. 5868, Port Hood Formation, Cape Breton Island, St. Rose, Inverness County. a: Bell, 1966, pl. IV, fig. 5 (GSC 15051), b: pl. IV, fig. 8 (GSC 15045). Previously figured as Adiantites oblongifolius Göppert. c-f. Loc. 1391, Port Hood Formation, Cape Breton Island, 4,000 ft NE of Chimney Corner, Inverness County. c: Bell, 1944, pl. XVI, fig. 3 (GSC 11029). d: pl. XVI, fig. 4 (GSC 11026), e: pl. XVII, fig. 5 (GSC 11028 - part of S. licens holotype). f: pl. XVII, fig. 2 (GSC 11022). Previously figured as Sphenopteris licens Bell. g. Loc. 854, Boss Point Formation, Nova Scotia, East branch River Philip, Oxford area, above Collingwood. - Bell, 1944, pl. LIX, fig. 1 (GSC 5552). Previously figured as Sphenopteris licens Bell. 

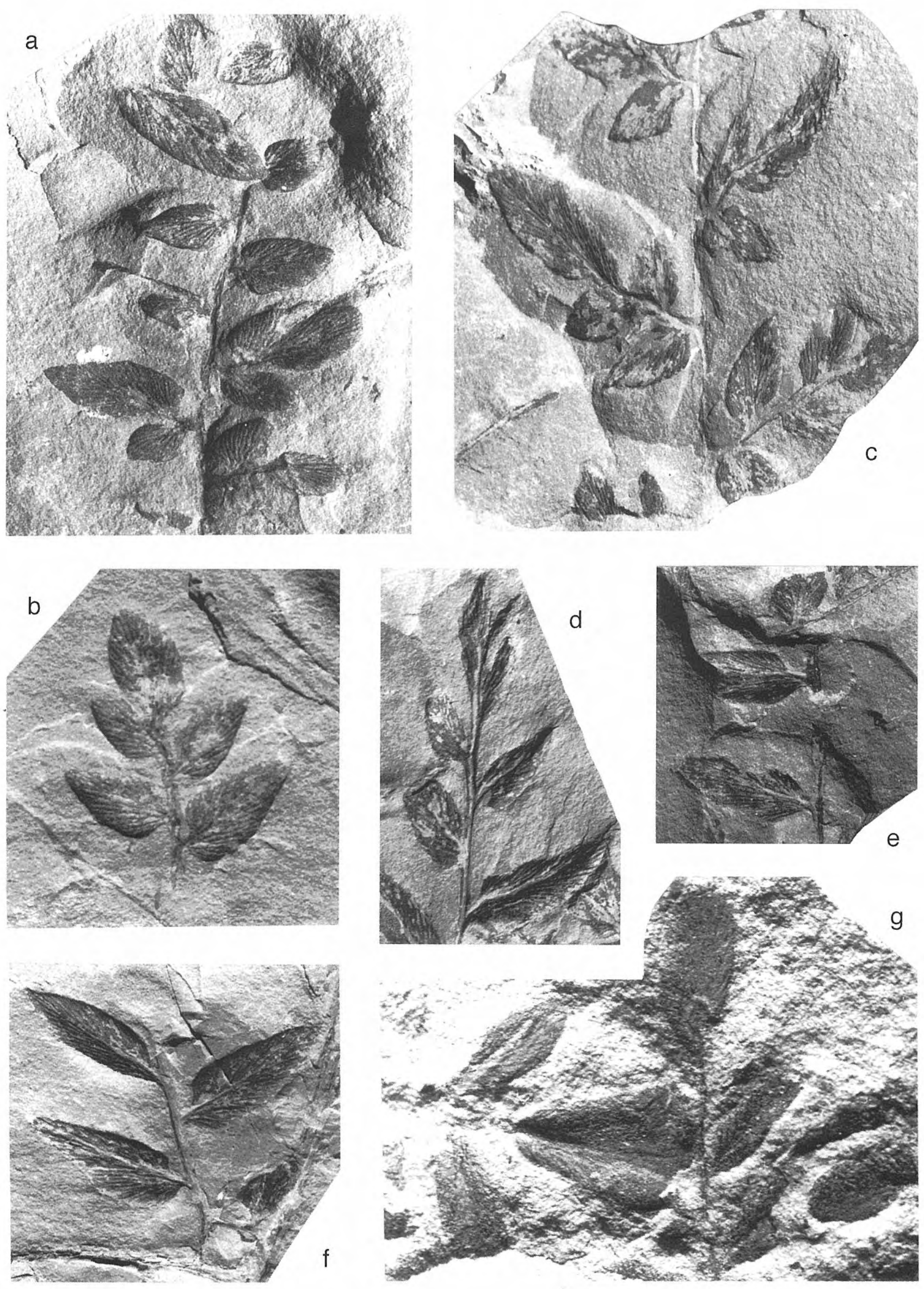
midrib in the basal part of the larger folioles. Lamina moderately vaulted. Reproductive structures unknown.

\section{Comparisons}

Pseudadiantites oblongifolius (Göppert) comb. nov. (basionym Adiantites oblongifolius Göppert, 1836) has apparently larger folioles, which are otherwise quite similar to those of Pseudadiantites sessilis (compare Göppert, 1836, Taf. XXI, figs 4-5, and Stur, 1877, Taf. XVII (XXXIV), figs 2-5).

Pseudadiantites rhomboideus (Ettingshausen) comb. nov. possesses consistently larger folioles ranging in shape from ovate to obovate, with trilobate elements in the basal part of the foliar structure.

\section{Discussion}

The specimen originally figured by Von Roehl (1868, Taf. XVI, figs 1, 1a) as Cyclopteris oblongifolia Goeppert var. sessilis Von Roehl is a small bipinnate element with the characteristically large terminal folioles and small, ovate lateral ones. Potonié (1896, p. 19) raised the var. sessilis to species rank, and figured side by side drawings of Adiantites oblongifolius Göppert from the lower Namurian of Lower Silesia, Czech Republic/Poland (Intrasudetic Basin) and upper Namurian (Yeadonian) of the Ruhr district in western Germany (Paralic Coal Belt). The morphological difference between these two taxa is apparently very minor. The specimen figured as a drawing by Potonié (1896, fig. 2) was subsequently illustrated photographically by Gothan (1929, Taf. 14, figs 1, 1a) and Leggewie (1966, Taf. 4, figs 1, 1a). Kidston (1923) figured a small specimen with more obovate folioles and, in some of these, a short midrib. He regarded this specimen as not wholly characteristic, but subsequent authors recognised it as correctly attributed to "sessilis". This specimen originated from Duckmantian strata in North Staffordshire, England. An upper Namurian (Yeadonian) specimen with partly overlapping folioles was illustrated from Belgium by Stockmans and Willière (1952). As Leggewie (1966) has pointed out, Gothan (1953) had a curious lapse of memory and briefly diagnosed a Neuropteris flabellinervis Gothan which was none other than Pseudadiantites sessilis (Roehl) Gothan. He figured two specimens from Duckmantian strata in the Ruhr district, western Germany. One of these specimens was refigured by Leggewie (1966, Taf. 1, fig. 2), who also attributed a specimen figured by Gothan (1953, Taf. 20, figs 1, 1a) as Neuropteris heterophylla (small pinnuled form) to what he called Palaeopteridium sessilis
(Potonié) Leggewie (Leggewie, Taf. 1, fig. 1). This specimen seems to have been incorrectly assigned and has been identified as Neuropteris loshii Brongniart by Laveine (1967, p. 145). Several workers on the Ruhr floras (Fiebig, 1957; Rabitz, 1957; Josten, 1962) employed Neuropteris flabelliformis Gothan before Leggewie (1966) pointed out its identity with Pseudadiantites sessilis. Additional specimens from the lower Westphalian of western Germany were also figured by Leggewie (1966), who mentioned that the organisation of Pseudadiantites sessilis was similar to that of Palaeopteridium reussii (Ettingshausen) Kidston. Despite a lack of information on the reproductive organs of Von Roehl's taxon, he opted for including it with Palaeopteridium, a probable Noeggerathialean. Leggewie (1966) speculated on a possible link between "Palaeopteridium" sessilis and Discinites jongmansii Hirmer, but these two organ species have never been found together. It is noted here that structurally $P$. sessilis also resembles other genera such as Triphyllopteris and it seems that Leggewie (1966) may have been too hasty in attributing Von Roehl's taxon to Palaeopteridium. It is preferred here to retain Pseudadiantites.

Bell (1944, p. 69, pl. XVI, figs 3-4, pl. XVII, figs 2-3, 5, pl. LIX, fig. 1) figured and described a new species, Sphenopteris licens Bell, which he compared with Adiantites oblongifolius Göppert, and distinguished on the basis of the more narrow or bluntly pointed apices of its folioles. However, in a later paper (Bell, 1966, pl. IV, figs $5,8,10)$ he figured three specimens as Adiantites oblongifolius, which cannot be satisfactorily distinguished from Sphenopteris licens. Bell did not compare with Pseudadiantites sessilis, i.e. the form that Von Roehl (1868) regarded as a variety of Göppert's species. It is noted that the three specimens figured by Bell (1966) show a range in size of the folioles that approaches in his fig. 10 that of Pseudadiantites rhomboideus (Ettingshausen). In the present paper several specimens figured by Bell as Sphenopteris licens and Adiantites oblongifolius are figured side by side under Pseudadiantites sessilis. Although the material described as Sphenopteris licens Bell shows a somewhat laxer arrangement of folioles, the size and shape of these stalked leaves appear identical to those figured later under the name of Adiantites oblongifolius. Indeed, the widely spaced folioles compare with the lax foliage of Adiantites oblongifolius Göppert, which is only distinguished on the generally larger size of its leaves. Whether or not it is justified to make a specific distinction on leaf size only, is an open question. The

Figure 3. a-c. Pseudadiantites rhomboideus (Ettingshausen) comb. nov. a. Loc. 1462, Parrsboro Formation, Cumberland County, Minas Basin shore, east of Moose Creek, Nova Scotia. Bell, 1944, pl. IV, fig. 6 (GSC 11044). Previously figured as Sphenopteris rhomboidea (Ettingshausen) Bell. Natural size. b-c. Loc. 1928, Parrsboro Formation, Parrsboro shore of Minas Basin, Nova Scotia. - Bell, 1944, pl. VI, fig. 6 (GSC 10969 - erroneously attributed to loc. 1364 in Bell's plate explanation). Previously figured as Sphenopteris lineata Bell (holotype). b, x 1; c, x 3. d-e. Pseudadiantites sessilis (Roehl) Gothan, x 3. Loc. 1391, Port Hood Formation, Cape Breton Island, c. 4,000 ft NE of Chimney Corner, Inverness County. Previously unfigured fragments (GSC 11022). (Other side of specimen figured in Bell, 1944, pl. XVII, fig. 2, as Sphenopteris licens Bell.) 


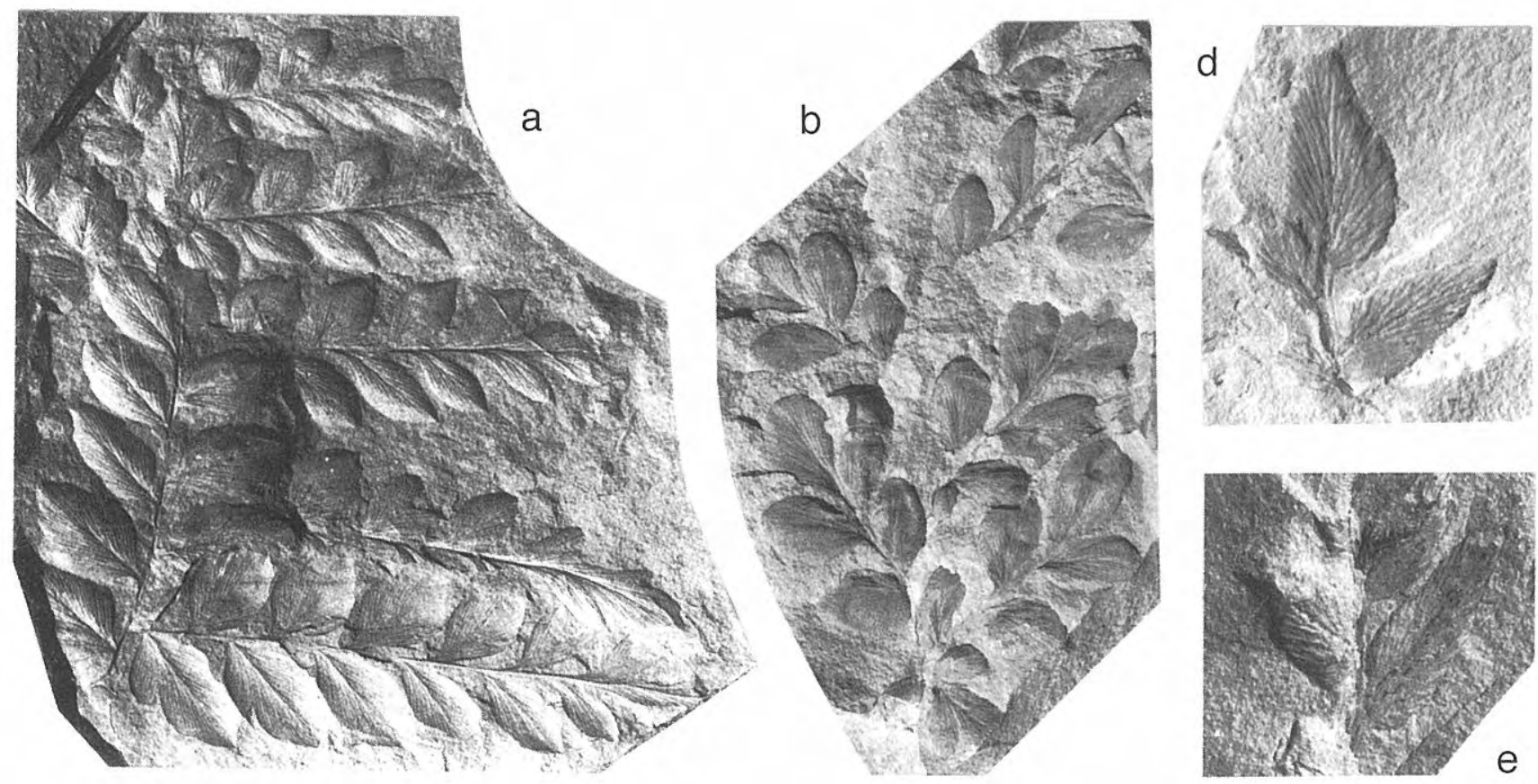

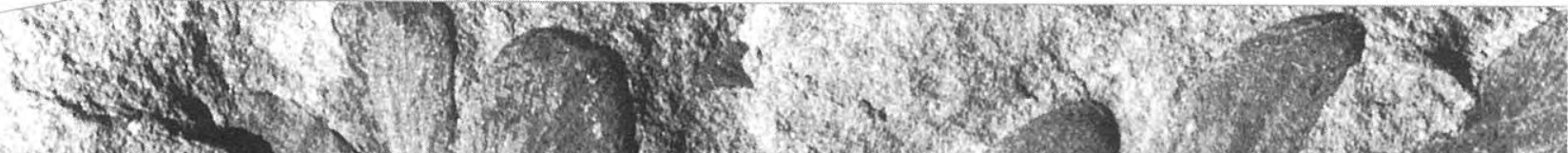

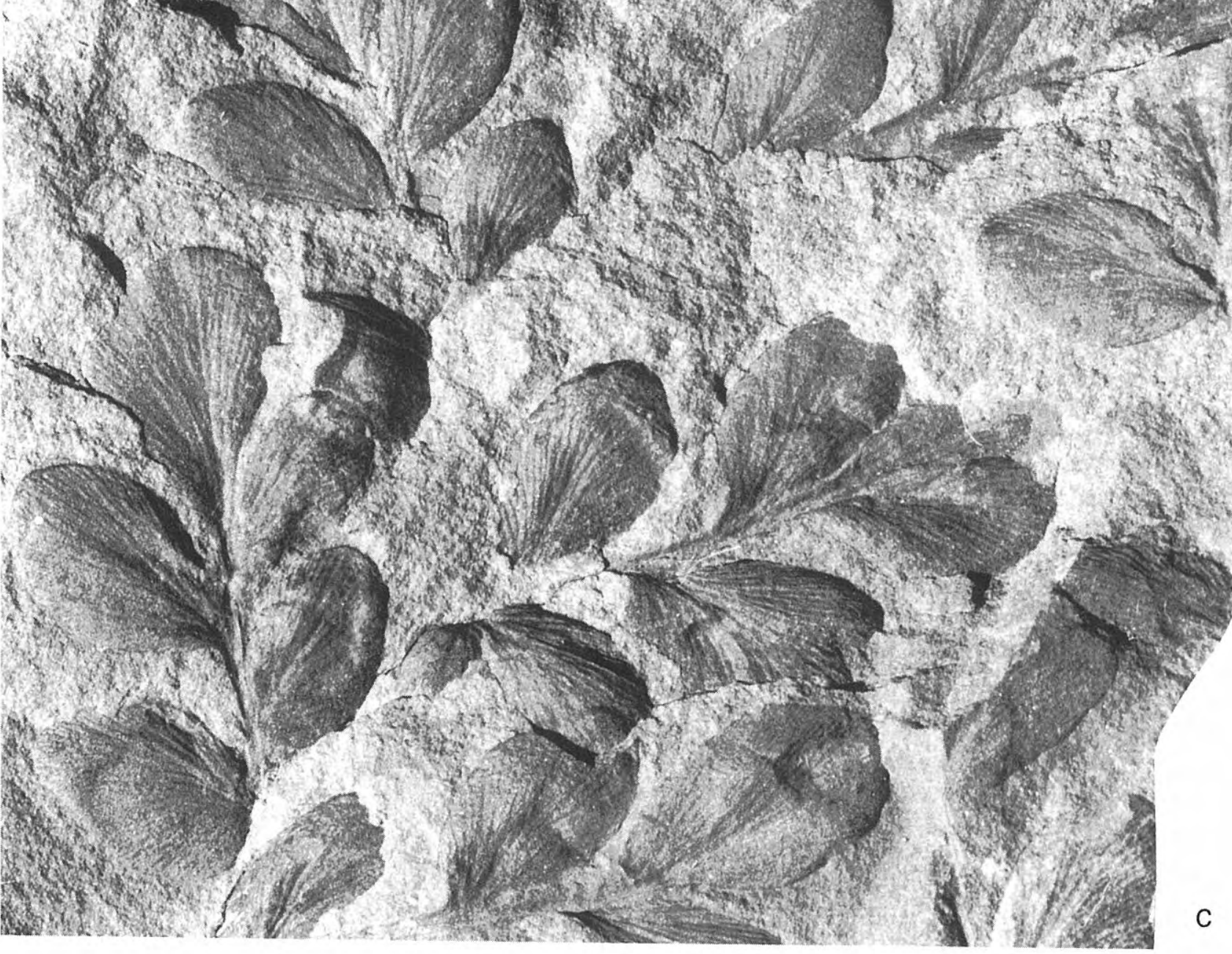


material figured as Pseudadiantites sessilis (or Palaeopteridium sessilis - see Leggewie, 1966) shows more closely spaced, partly overlapping folioles of the size and shape shown by the specimens from Nova Scotia. The venation is identical in all cases. It is preferred here to regard the spacing of the folioles as less important than their average size, and thus assign the material from Nova Scotia to Pseudadiantites sessilis rather than Pseudadiantites oblongifolius. It is admitted that this decision may be regarded as somewhat arbitrary (as is often the case with palaeobotanical species based on fragmentary remains).

The specimens figured and described as Sphenopteris licens Bell came from localities 854 and 1391, both ascribed to the Riversdale Group (i.e. the lower part of the Cumberland Group as understood at present), but from different parts of Nova Scotia. The remains figured later as Adiantites oblongifolius came from the Port Hood Formation, Inverness County, St Rose Coalfield, Shale Zone 17, also in the lower part of the succession (loc. 5868).

Previously, Bell (1940) had figured and described an Adiantites poolii Bell from the Pictou Coalfield (Stellarton Basin) in Nova Scotia. He compared with both A. oblongifolius and A. rhomboideus, two species which are closely similar to each other, and which are both assigned to Pseudadiantites in the present paper. However, "Adiantites" poolii is apparently a neuropterid. This species is based on a single specimen (holotype GSC 10924), from Bolsovian (?) strata in the Stellarton Basin. It is reasonably well figured (Bell, 1940, pl. IV, fig. 7). The present writer has been able to reexamine this specimen in the GSC collections in Ottawa. It shows a vein pattern that is not fan-shaped as in Pseudadiantites, and its frond is probably fully planated and not "pseudopinnate" as in Pseudadiantites.

Potonié and Gothan (1921, p. 78) mentioned that the rhomboidal-ovate folioles of Adiantites oblongifolius were quite different from the cuneate leaves of more characteristic species of Mississippian age (Kulm in the German usage), such as Adiantites tenuifolius Göppert, Adiantites machanekii Stur, and Adiantites antiquus Stur. This implied that "Adiantites" oblongifolius Göppert should be removed from Adiantites as they understood the genus. Although Gothan (1929) did not draw this conclusion, its proper attribution may well be to Pseudadiantites and this is the solution proposed in the present paper. This leaves the vexed question of the correct specific attribution of Pseudadiantites sessilis, which is very similar to Pseudadiantites oblongifolius (Göppert) comb. nov. Leggewie (1966) concentrated on "sessilis" and did not discuss Göppert's species which has rarely been used in the literature.

Additional remains of Pseudadiantites sessilis from western Germany were figured from Yeadonian, Langsettian and Duckmantian strata by Josten (1983, 1991). Pseudadiantites sessilis has most recently been recorded from the Duckmantian of Southwest Spain (Álvarez-Vázquez, 1995). Although this material is very fragmentary, it seems correctly assigned to this species.
Occurrence: Yeadonian to Duckmantian of western Europe and Kinderscoutian (?) to Yeadonian of eastern (Atlantic) Canada.

Canadian specimens assigned to Ps. sessilis: GSC 5552, 11022, 11025, 11026, 11028, 11029, 15045, 15051, 15052. Localities 854 (brook East of East River Philip Station, C.N.R., Oxford area, Nova Scotia, Boss Point Formation of Tatamagouche Syncline), 1391 (Northeast of Chimney Corner, Inverness County, Cape Breton Island, Port Hood Formation), 5868 (shale zone 17, St. Rose Coalfield, Inverness County, Cape Breton Island, Port Hood Formation).

\section{Pseudadiantites rhomboideus (Ettingshausen) comb. nov.}

Figs. 3a-c, 4, 5b-c

* 1852 Cyclopteris rhomboidea Ettingshausen, p. 12, Taf. II, fig. 5.

1869 Triphyllopteris rhomboidea (Ettingshausen); Schimper, p. 480.

1886 Adiantites rhomboideus (Ettingshausen); Kidston, p. 83.

1899 Triphyllopteris rhomboidea (Ettingshausen); Hofmann und Ryba, p. 49, Taf. X, fig. 7.

? 1914 Adiantites obtusus (Dawson); Stopes, p. 56-58, pl. XVI, fig. 42.

1923 Adiantites rhomboideus (Ettingshausen); Kidston, p. 187.

1923 Adiantites Wardi Kidston, p. 194-196, pl. XI, figs 23, pl. XLI, fig. 5, pl. XLVII, figs 3, 3a.

1926 Triphyllopteris rhomboidea (Ettingshausen); Trapl, p. 37, Tab. III, fig. 1. (fide Němejc, 1928).

1928 Triphyllopteris rhomboidea (Ettingshausen) Schimper; Němejc, p. 80-82, pl. X, figs 1-7.

1944 Sphenopteris rhomboidea (Ettingshausen); Bell, p. 59, pl. III, figs 8-10, pl. IV, fig. 6.

*1944 Sphenopteris lineata Bell (pars), p. 62, pl. V, fig. 4, pl. VI, fig. 6 (holotype), pl. X, fig. 1(?), pl. XII, fig. 1; non pl. VI, fig. 2 (= Neuropteris ghayei Stockmans et Willière), non pl. VII, fig. 4 (= Adiantites adiantoides (Lindley and Hutton) Kidston).

1944 Adiantites obtusus (Dawson); Bell, p. 56, pl. II, figs 2, 5, pl. III, fig. 4.

1954 Mariopteris sp. Stockmans et Willière, pl. I, fig. 7.

1954 Triphyllopteris rhomboidea (Ettingshausen); Gothan, p. 245, Taf. IV, fig. 1a (copy after Ettingshausen, 1852, Taf. II, fig. 5), fig. 1 b.

1957 Triphyllopteris rhomboidea (Ettingshausen); Gothan und Remy, p. 182, Abb. 186.

1959 Triphyllopteris rhomboidea (Ettingshausen); Remy und Remy, p. 136, Abb. 105.

1966 Adiantites obtusus (Dawson); Bell, pl. V, fig. 17, pl. VI, fig. 1, pl. VIII, fig. 1 ?.

1966 Sphenopteris lineata Bell (pars); Bell, pl. III, fig. 8 (holotype - after Bell, 1944, pl. VI, fig. 6), non pl. III, fig. 7 (= Adiantites adiantoides (Lindley and 


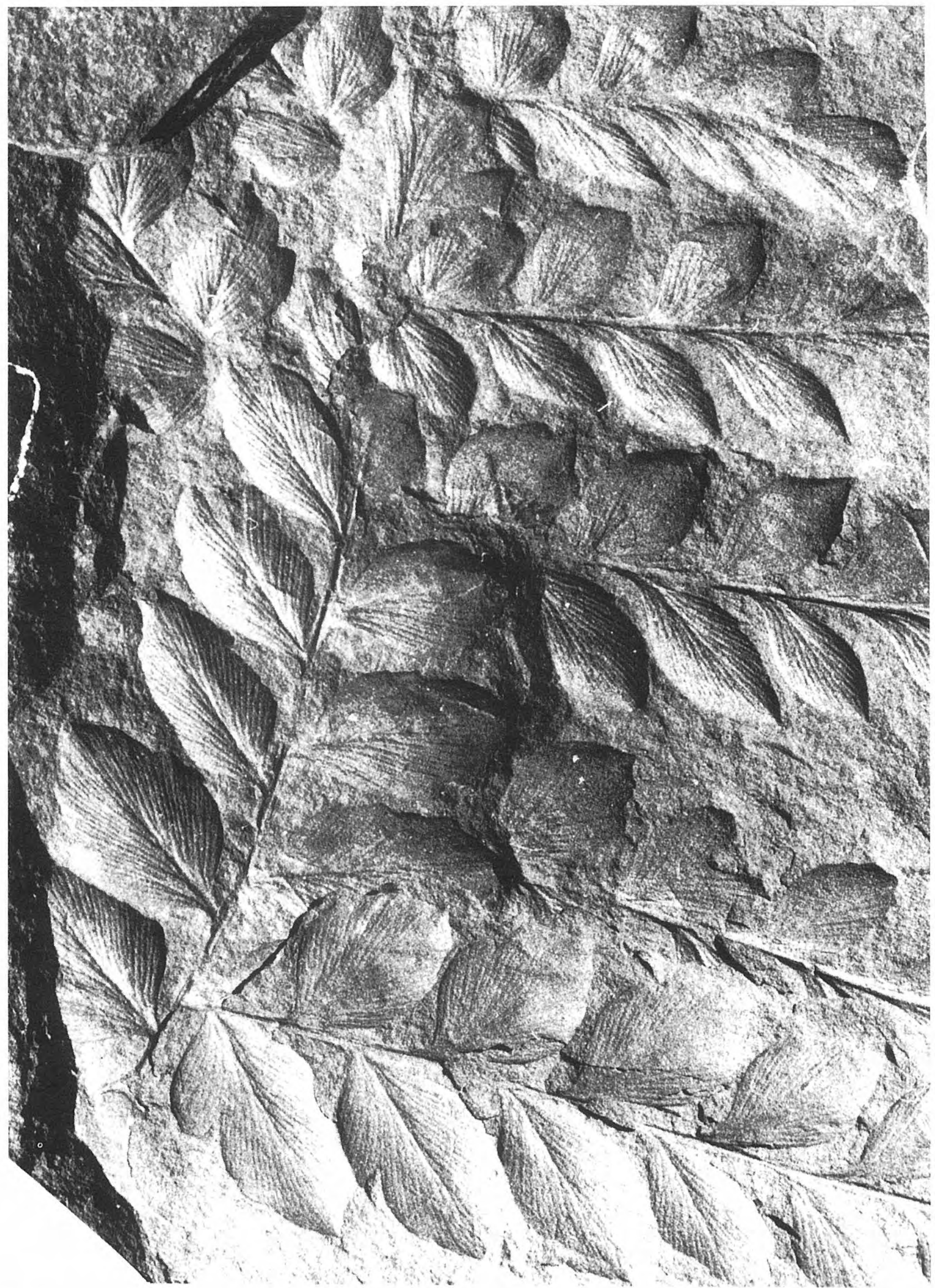

Figure 4. Pseudadiantites rhomboideus (Ettingshausen) comb. nov., x 3 (enlargement of Fig. 3a). 
Hutton) Kidston), pl. IV, fig. 11 (= Neuropteris ghayei Stockmans et Willière).

1975 Triphyllopteris rhomboidea (Ettingshausen); Boureau et Doubinger in Boureau, p. 655-656.

1977 Triphyllopteris rhomboidea (Ettingshausen); Remy und Remy, p. 192, 194, Abb. 81 (copy after Gothan und Remy, 1957, Abb. 186).

?1979 "Triphyllopteris" rhomboidea (Ettingshausen); Anisimova, p. 62-63, Tab. XXXI, figs 5-6 (fragmentary and poorly illustrated specimens which may have been correctly identified).

\section{Excludendum}

1976 Sphenopteris cf. rhomboidea (Ettingshausen); Oleksyshyn, p. 164, Fig. 11 A (indeterminable).

\section{Diagnosis}

Pseudopinnate branching structures bearing stalked folioles, either entire and ovate-obovate or consisting of lobate to pinnate elements. Venation characteristically fan-shaped, showing a short midrib or absence thereof and thin though well-marked, densely arranged nervules, almost straight or slightly arching. Lamina vaulted.

\section{Comparisons}

Pseudadiantites sessilis (Roehl) Gothan is very similar to Ps. rhomboideus, but has generally smaller foliar elements, as well as showing a more restricted range of foliar morphology which does not seem to include the pinnate forms as occur in Ps. rhomboideus.

Pseudadiantites oblongifolius (Göppert) comb. nov. shows the same limited range in the morphology of folioles as Ps. sessilis, but has larger folioles as in Ps. rhomboideus.

Adiantites adiantoides (Lindley and Hutton) Kidston has more rounded, entire folioles tending to a more nearly subcircular outline. These possess a fan-shaped venation without a midrib. Fragmentary remains can possibly be confused with those of Pseudadiantites rhomboideus in the lower part of the pseudopinnate frond.

\section{Description and Discussion}

Ettingshausen (1852, p. 12) diagnosed his "Cyclopteris" rhomboidea as follows: "fronde pinnata, pinnis alternis, approximatis, patentibus, pinnulis alternis rhomboideis vel obovatis, coriaceis, inaequalibus, basi in petiolum brevissimum attenuatis, terminalibus majoribus rhomboideis, margine undulatis vel lobatis; nervis creberrimis, flabellatis, dichotomis, rhachide subflexuosa." He stated that this species was not uncommon in Stradonitz (Strádonice), Bohemia (Czech Republic). The figured specimen (holotype) is a near-apical shoot fragment with partially overlapping folioles, rhombic to obovate in shape, as mentioned in the description. A pinnate element is partially preserved in the lower part of the specimen.

The most complete representation of this species, also from the Lísek Coalfield, Strádonice, was figured by Nĕmejc (1928). His illustrations show the characteristic ovate to obovate, stalked folioles with fan-shaped venation, as well as pinnate folioles. Whereas the simple folioles display bluntly pointed apices, the pinnate elements show somewhat more rounded apices, particularly where the pinnate structure is most highly developed. In the basal part of the pinnate elements there are lobed pinnules of somewhat more rounded aspect. These specimens thus display a certain amount of morphological variation within the alternately arranged, subopposite folioles. Nĕmejc (1928, p. 81) described the morphological variation and gave the following diagnosis: "Partes foliorum adhuc cognitae bi-vel vix tripinnatae, pinnis alternantibus. Pinni primarii fere 15 $\mathrm{cm}$ longi $45 \mathrm{~mm}$ lati. Pinnuli ultimi obovatorhomboidales, saepe lobati, vix inaequilaterales, basi in petiolum brevissimum attenuati, 15-30 mm longi, 8-17 mm lati, nervo centrali tenuo atque in mediam ver tertiam partem attingenti praeditae. Nervi secundarii furcati. Truncus ac fructificatio - ?".

Additional specimens from the Strádonice area in central Bohemia were figured by Hofmann and Ryba (1899), Gothan (1954, Taf. 4, fig. 1b), Gothan and Remy (1957, Abb. 186), and Remy and Remy (1959). Particularly significant is the specimen figured by Gothan and Remy (1957), which represents several branches in the lower part of the foliar structure showing the transition from single, ovate folioles to pinnate elements with more rounded lobes. The transition from entire folioles to pinnate ones is more rapid than that shown in Nĕmejc (1928, Tab. X, fig. 1).

The specimens illustrated by Bell (1944, pl. III, figs 810, pl. IV, fig. 6) under the name of Sphenopteris rhomboidea (Ettingshausen) Bell, all from locality 1462, Parrsboro Formation, Minas Basin, east of Moose Creek, Cumberland County, Nova Scotia, show the large, ovate to obovate folioles with bluntly pointed apices which constitute the most characteristic form of Pseudadiantites rhomboideus. These folioles show a relatively well developed central vein which compares with some of the larger folioles in Nĕmejc's (1928) specimens (e.g. Tab. $\mathrm{X}$, fig. 3, upper part). There is no doubt about the correct attribution of these specimens. The most significant specimens are refigured here as Figs. 3a, 4, 5b-c.

On the other hand, it is difficult to see why Bell (1944, p. 62) introduced the species Sphenopteris lineata

Figure 5. a. Adiantites adiantoides (Lindley and Hutton) Kidston, x 3. Loc. 879, Boss Point Formation, Nova Scotia, River Philip south of mouth of Racetrack Brook, Oxford Junction. - Bell, 1944, pl. VII, fig. 4 (GSC 5947). Previously figured as Sphenopteris lineata Bell. b-c. Pseudadiantites rhomboideus (Ettingshausen) comb. nov., x 3 . Loc. 1462, Parrsboro Formation, Minas Basin shore, east of Moose Creek, Cumberland County, Nova Scotia. -b. Bell, 1944, pl. III, fig. 9 (GSC 11047, counterpart GSC 9371). -c. Bell, 1944, pl. III, fig. 10 (GSC 11046). Previously figured as Sphenopteris rhomboidea (Ettingshausen) Bell. 


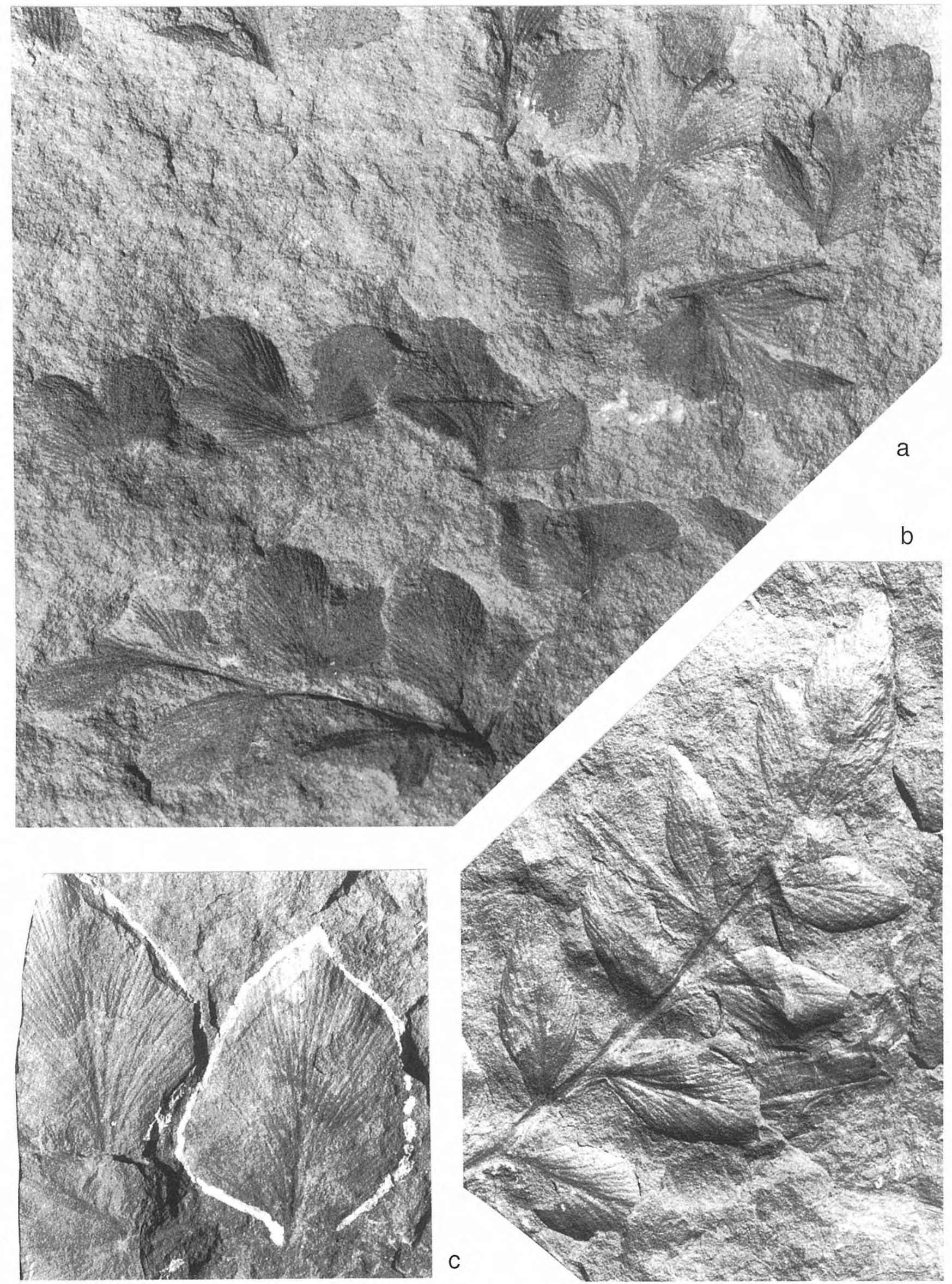


Bell, the holotype of which (Bell's pl. VI, fig. 6, refigured in Bell, 1966, pl. III, fig. 8) shows partially stalked, ovate to obovate folioles, mainly entire but partly lobate. This specimen from locality 1928, Parrsboro shore of Minas Basin (the reference to loc. 1364, Joggins section, in Bell's plate explanation, is in error), apparently differs only in possessing folioles which are more commonly obovate rather than ovate, and which show correspondingly more rounded apices. It is refigured here as Figs. 3b, c. Bell (1944, p. 62) compared with several species of Eusphenopteris and also with Adiantites adiantoides (Lindley and Hutton) Kidston, but not with "Sphenopteris" rhomboidea. This is remarkable, but it seems that Bell did not have access to the monograph published by Nĕmejc (1928) in which the morphological variation of Ettingshausen's species had become apparent. The specimen of Sphenopteris lineata figured on Bell's (1944) pl. V, fig. 4, is a small fragment from locality 1411, Parrsboro Formation, Minas Basin, mouth of Moose River, east side. This may also be assigned to Pseudadiantites rhomboideus. An additional, fairly large specimen from locality 879 , Oxford Junction, on River Philip south of mouth of Racetrack Brook, which was also figured by Bell (1944, pl. VII, fig. 4) as Sphenopteris lineata, shows a majority of pinnate elements with rounded lobes and apices, although a few ovate, entire folioles are also in evidence. This specimen is here attributed to Adiantites adiantoides, even though some of its folioles tend to be trilobate. It is refigured here as Fig. 5a. The specimen figured as Sphenopteris lineata on Bell's pl. X, fig. 1, from loc. 878, West Bay, Parrsboro, is poorly preserved and can only be identified as Pseudadiantites sp. indet.

Additional specimens attributed by Bell to Sphenopteris lineata include two remains (Bell, 1944, pl. VI, fig. 2; Bell, 1966, pl. IV, fig. 11) from locality 3100 , Harrington River, Cumberland County, which show a fully planated frond structure and which can be identified as Neuropteris ghayei Stockmans and Willière. Bell compared with three species of Eusphenopteris, i.e. E. schillingsii (Andrä), E. obtusiloba (Brongniart) and E. striata (Gothan), but these comparisons seem irrelevant in view of the pseudopinnate branching structure of the holotype of "Sphenopteris" lineata (Figs. 3b-c of the present paper). He also compared with Adiantites adiantoides (Lindley and Hutton) Kidston which is nearer to the mark.

Bell (1944, p. 56, pl. II, fig. 5, pl. III, fig. 4) identified as Adiantites obtusus (Dawson) Stopes three fragmentary specimens from locality $2254(=804)$, Fern Ledges, Duck Cove, St. John, New Brunswick. These show large ovate and obovate folioles, partly belonging to pinnate elements, which fit within the range of morphological variation of Pseudadiantites rhomboideus. One of these specimens (GSC 15030) has been reexamined by the present writer. It is likely that the Adiantites obtusus (Dawson, non Lesquereux) figured by Stopes (1914, pl. XVI, fig. 42), should also be included in the synonymy. This specimen had previously been figured by Dawson (1871, pl. XVI). Stopes (1914, p. 56-58) discussed at length the nomenclatorial confusion surrounding this specimen which she regarded as being the same taxon as "Noeggerathia" bockschiana Lesquereux (1858). Although she opted for the generic attribution Adiantides (= Adiantites), which is quite relevant, she failed to compare with "Adiantites" rhomboideus (Ettingshausen) Kidston. Her detailed comparison with Cyclopteris adiantopteris Weiss (in Potonié, 1893), a probable synonym of Ulvopteris crenulata (Brongniart) comb. nov. (basionym Neuropteris crenulata Brongniart), is irrelevant. The full synonymy of Adiantites obtusus (Dawson) Stopes, as given by Stopes (1914, p. 56), is not incorporated in the synonymy of Pseudadiantites rhomboideus because of the fragmentary nature of the specimens figured and the fact that Lesquereux's (1858, 1879) illustrations are diagrammatic drawings, which cannot be judged properly.

Adiantites wardii Kidston (1923, p. 194-196, pl. XI, figs 2-3, pl. XLI, fig. 5, pl. XLVII, figs 3, 3a) is here regarded as a synonym of Pseudadiantites rhomboideus. Both entire, ovate folioles and lobate (generally trilobate) elements occur in the specimens figured by Kidston from Duckmantian strata in Staffordshire, England. It is noted that the size of folioles appears a little smaller in the British material. Kidston (1923) did not compare with Ettingshausen's species, which was not well known at the time. One is left wondering if the comparable species Adiantites bondii Kidston (1923, p. 192, pl. XLIV, fig. 5, pl. XLVII, fig. 2), figured and described on the basis of a single, very fragmentary remain, should be regarded as identical to Pseudadiantites rhomboideus. This small specimen, which may also be compared with Eusphenopteris, is too fragmentary for a proper identification.

Triphyllopteris rhombifolia Daber, from the Viséan of Doberlug-Kirchhain in eastern Germany, is similar in all respects including the apparently pseudopinnate branching structure. Unfortunately, this species is only known from fragmentary remains (Daber, 1959, p. 19, Abb. 12, Taf. II, figs 1-2) which do not allow a full comparison. Daber does not compare with "Triphyllopteris" rhomboidea, possibly because of the difference in age. The fragmentary nature of the material figured by Daber prevents establishing its synonymy. The even more fragmentary remains figured by Wagner et al. (1983, pl. 5) from Viséan strata at Berlanga in Sierra Morena, southwest Spain, as Adiantites cf. rhombifolia (Daber), show large, entire folioles which do not fit Pseudadiantites rhomboideus. These remains have recently been referred tentatively to Charbeckia Knaus et

Figure 6. Rhacopteridium speciosum (Ettingshausen) Hirmer, x 3. Loc. 854, Boss Point Formation, Nova Scotia, East Branch River Philip, Oxford area, above Collingwood. - Bell, 1944, pl. XIV, fig. 6 (GSC 5568). Previously figured as Sphenopteris oxfordensis Bell (holotype). 


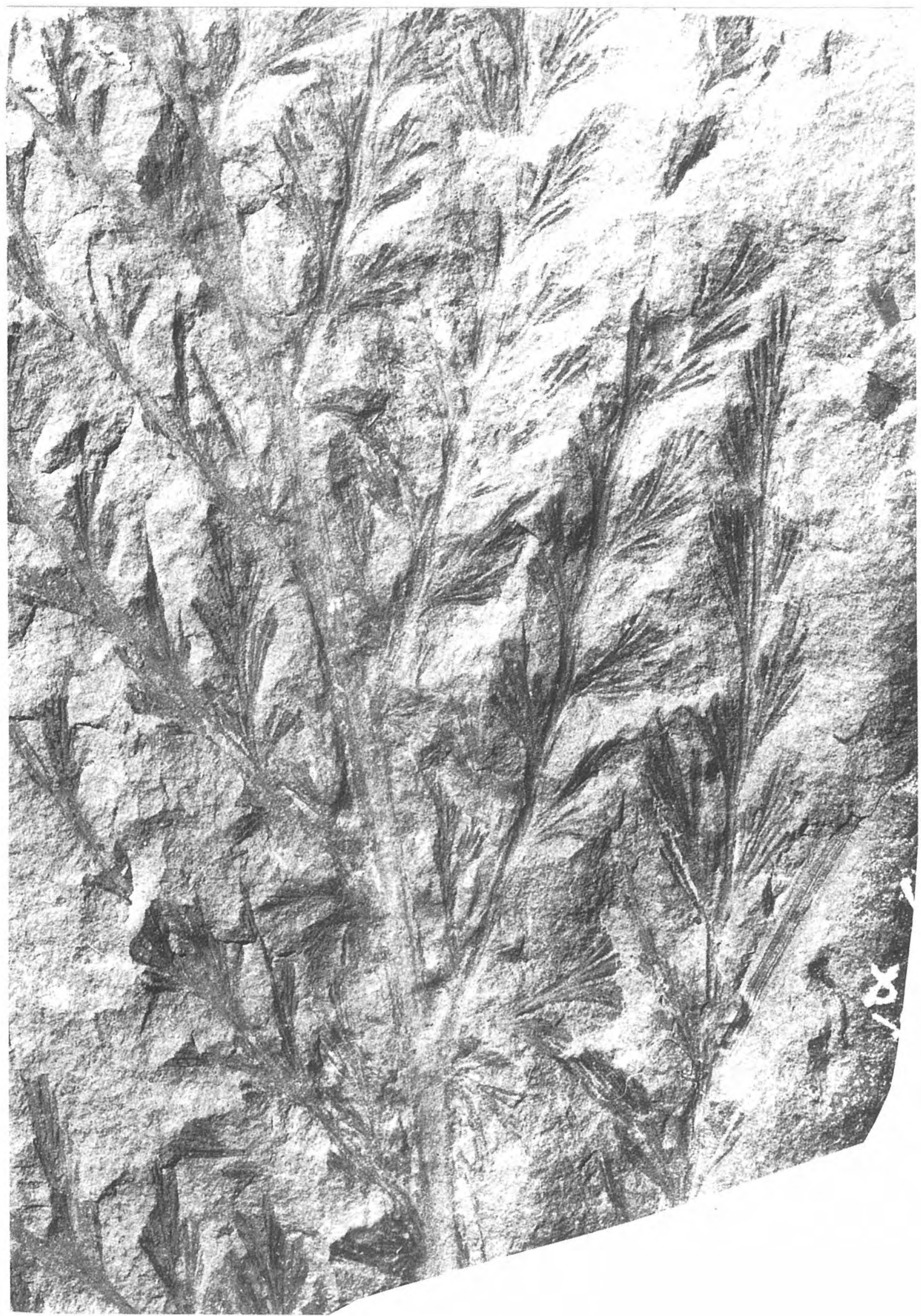


al. (2000), another genus with folioles showing a fanshaped venation. More complete specimens from Sierra Morena would be desirable.

Occurrence: Pseudadiantites rhomboideus (Ettingshausen) has been recorded repeatedly from middle Westphalian strata in central Bohemia, and European authors regarded it as an endemic form of the Central European area, even after Bell had noted its presence in Nova Scotia. However, a specimen figured as Mariopteris sp. by Stockmans and Willière (1954) from Langsettian strata in Belgium appears to be attributable to Pseudadiantites rhomboideus, and Adiantites wardii Kidston, from the Duckmantian of England, may also be assigned to this species. Although undoubtedly rare, it is geographically much more widespread than the Czech, German and French authors have assumed. This is also suggested by a record from the Caucasus (Anisimova, 1979), which may be correct, although the quality of her illustrations leaves much to be desired. Bell (1944, p. 59) identified Ettingshausen's species from two localities in Nova Scotia and New Brunswick, but only figured remains from loc. 1462, which is in the Parrsboro Formation of the Minas Basin. The other locality, 828, St. John county, New Brunswick, east of Dixon Point at McCoy Head, is in the Cumberland Group without further precision. This record is not backed by illustration, and is held in abeyance. Sphenopteris lineata Bell seems to correspond primarily to Pseudadiantites rhomboideus, but one record, from loc. 3100 , seems to belong to another type of plant, Neuropteris ghayei. Other remains, from loc. 879, are assigned to Adiantites adiantoides. Since Bell's usage of Sphenopteris lineata has not been consistent, his long list of localities cannot be taken as uniformly corresponding to Pseudadiantites rhomboideus. This leaves localities 1392, 1411 and 1928 as confirmed records. Remains figured by Bell (1944) as Adiantites obtusus are all from locality 2254 $(=804)$. Pseudadiantites rhomboideus has been recorded from Langsettian to Bolsovian (?) strata in Europe, but it probably ranges more extensively.

Canadian specimens assigned to Ps. rhomboideus: GSC 217, 472, 5947, 11044, 10969, 15030, 15032. Loc. 804 (=2254) ("Fern Ledges", Duck Cove, St. John County, New Brunswick), 1392 (Whale Cove, Inverness County, about ${ }^{1 / 4}$ mile south of Grey Point), 1411 (mouth of Moose River, East side, Minas Basin shore, Parrsboro Formation), 1462 (East of Moose Creek, Cumberland County, Minas Basin, Parrsboro Formation), 1928 (West Bay of Parrsboro shore, Minas Basin).

\section{Genus Rhacopteridium Hirmer 1940}

\section{Diagnosis}

Frond of average size, with strong rachis, nearly $1 \mathrm{~cm}$ wide at base, twice pinnate; first order pinnae very precisely alternate in two rows and $2-2^{1 / 2} \mathrm{~cm}$ distant on the rachis; up to $15 \mathrm{~cm}$ long and up to a little over $2 \mathrm{~mm}$ wide. Ultimate pinnae inserted at regular intervals of about $1 \mathrm{~cm}$. These are cuneate at the base, lanceolate overall; in their distal part split into several (mostly 4-5) segments which are split in turn distally into two or three parts. Pinnae weakly anadromously developed. Basal anadromous pinnules of first order pinnae strongly developed. Lower part of frond more aphleboid pinnate, in which the first order pinnae appear increasingly more planated and tending towards fusion with the less incised last order pinnae. Anadromous basal portions again strongly developed (after Hirmer, in Hirmer and Guthörl, 1940 , p. 51 - free translation from the German).

\section{Rhacopteridium speciosum (Ettingshausen) Hirmer \\ Figs. 6-7}

*1854 Noeggerathia speciosa Ettingshausen, p. 58, Taf. 13, Fig. 2.

1885 Rhacopteris (Noeggerathia) speciosa (Ettingshausen) Stur, p. 7.

1899 Rhacopteris elegans (Ettingshausen) Schimper pars; Hoffman und Ryba, Taf. XI, fig. 16 (acc. Nĕmejc, 1928).

1926 Rhacopteris elegans Schimper; Trapl, Tab. III, fig. 2.

1928 Rhacopteris speciosa (Ettingshausen); Nĕmejc, p. 72-74, pl. VII, figs 1-6, pl. VIII, figs 1-7.

1940 Rhacopteridium speciosum (Ettingshausen) Hirmer (in Hirmer and Guthörl), p. 48, 50.

*1944 Sphenopteris oxfordensis Bell, p. 66-67, pl. XIV, figs $1,5,7$.

1944 Sphenopteris pseudo-furcata Kidston; Bell, p. 69, pl. XVI, fig. 5, non fig. 1 (= Palmatopteris sp.?).

\section{Description}

A strongly developed main axis, $2 \mathrm{~mm}$ wide, carries stout lateral branches inserted at c. $45^{\circ}$ with several times bifurcate foliar elements inserted very obliquely in what appears to be a subopposite, alternate disposition. Each foliar element is stalked, laciniate, with a fan-shaped to branched disposition with the ultimate segments linear and pointed.

\section{Discussion}

The most complete representation of this species has been published by Nĕmejc (1928), who figured material only from Rakovník, although he mentioned its occurrence from the Kladno-Rakovník area as well as from Radnice and Plzen̆ in Bohemia, Czech Republic. The type locality is unknown, although Ettingshausen (1854) described it from the Radnitz (= Radnice) Coalfield. Nĕmejc (1928) has illustrated the considerable amount of variation in the size and shape of the foliar elements, and this has allowed the detailed generic diagnosis given by Hirmer. Hirmer in Hirmer and Guthörl (1940, p. 50) based the genus Rhacopteridium on Rhacopteris speciosa (Ettingshausen) Stur, pointing out that its bipinnate structure distinguishes this species from the monopinnate Rhacopteris, whereas the foliar elements show a rhacopterid habit. He also compared with Palaeopteridium reussii (Ettingshausen) Kidston. 


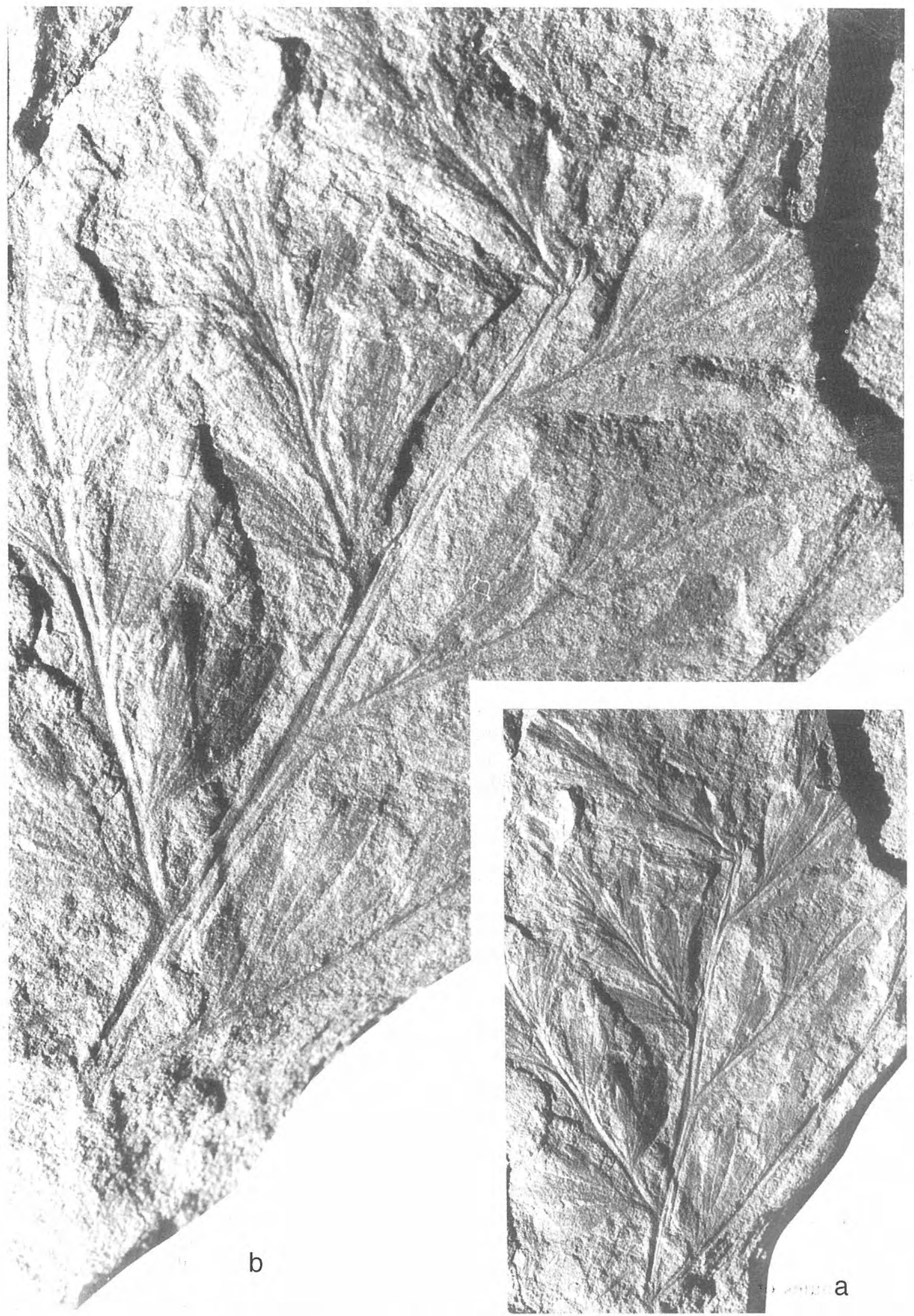

Figure 7. Rhacopteridium speciosum (Ettingshausen) Hirmer, x 3 (a), x 6 (b). Loc. 1462, Parrsboro Formation, Nova Scotia, Minas Basin shore, east of Moose Creek, Cumberland County. - Bell, 1944, pl. XVI, fig. 5 (GSC 9371). Previously figured as Sphenopteris pseudo-furcata Kidston. 
The specimen available from locality 854, East Branch River Philip, Oxford area, above Collingwood corner, Nova Scotia, figured and described by Bell (1944, pl. XIV, fig. 7) as Sphenopteris oxfordensis Bell (holotype), shows the laciniate foliar elements of the Bohemian species as well as the bipinnate structure which characterises Rhacopteridium Hirmer. In this respect there is an obvious resemblance with Palaeopteridium Kidston. This specimen (refigured here $\mathrm{x} 3$ as Fig. 6) shows foliar elements of smaller size than seems to be customary for Rhacopteridium speciosum, but this is not considered sufficiently important for distinction as a different species. An additional specimen figured by Bell (1944, pl. XIV, figs 1, 5) as Sphenopteris oxfordensis, from loc. 860 , is only a small fragment, although probably attributed correctly to this synonym of Rhacopteridium speciosum. Bell (1944, p. 67) compared his Sphenopteris oxfordensis with Sphenopteris coemansii Andrä, which also possesses laciniate foliar elements. However, these show a more spreading aspect than those of Rhacopteridium speciosum, and also seem to be less obliquely inserted. Sphenopteris coemansii apparently possesses a fully planated frond structure, whereas the structure of Rhacopteridium seems to have been pseudopinnate. For a recent description of Sphenopteris coemansii Andrä see Brousmiche (1983, p. 311).

The remains figured and described by Bell (1944, p. 69, pl. XVI, figs 1, 5) under the name of Sphenopteris pseudo-furcata Kidston, are also referred here to Rhacopteridium speciosum (Fig. 7). Two specimens from different localities were figured by Bell (1944) under this name. One of these remains (Bell, 1944, pl. XVI, fig. 5) shows a thin axial element on which thin lateral axes are inserted at an angle approximating $45^{\circ}$. These carry obliquely inserted (at c. $35-40^{\circ}$ ), stalked, palmate folioles in alternate to subopposite position; they are commonly split into two, less often three parts, each of which is split again at the apex. Although the apices are poorly preserved, it seems that the lobes end in ogival teeth. The nervation is fan-shaped, without a midrib, and radiates outwards from the stalked base. Length/breadth ratios are difficult to establish because the apical parts of folioles are poorly preserved and often seem to be incomplete, thus leaving some doubt about the proper length of a foliole, whilst the width cannot always be established either because of partial imbedding into the rock. Indeed, it seems that the folioles are forced into a position parallel to the bedding plane, and that the original structure was not fully planated. On the contrary, Kidston's holotype of what is presently called Palmatopteris pseudofurcata (Kidston) Susta does seem to show a planated frond structure. It is also noted that Palmatopteris pseudofurcata shows pinnule lobes with more rounded apices. The pinnules of Palmatopteris pseudofurcata appear to be less obliquely inserted than the folioles of Bell's specimen. The second specimen attributed to Sphenopteris pseudo-furcata (Bell, 1944, pl. XVI, fig. 1) is poorly preserved and probably a Palmatopteris $\mathrm{sp}$.
Occurrence: Radnice beds (Duckmantian - Bolsovian) of Central Bohemia; Boss Point and Parrsboro formations in Nova Scotia (Yeadonian or lower Langsettian).

Canadian specimens: GSC 5568. Loc. 854 (East branch of River Philip, Oxford area, above Collingwood Corner, Boss Point Formation of Tatamagouche Syncline). GSC 9371. Loc. 1462 (East of Moose Creek, Minas Basin shore, Cumberland County, Parrsboro Formation), both in Nova Scotia, constitute the first records checked reasonably from outside the Bohemian type area. GSC 5563. Loc. 860 (also East Branch River Philip, Nova Scotia). A third locality (3041), mentioned by Bell (1944, p. 67), has no illustrated record, and this specimen has not yet been checked in the collections.

\section{SIGNIFICANCE OF ADIANTITES, PSEUDADIANTITES AND RHACOPTERIDIUM}

These three morphogenera without a proper systematic attribution in the absence of reproductive structures, represent rare elements of mid? to upper Namurian and lower to mid-Westphalian flora. The paucity of the record is most likely due to environmental considerations. The nearest morphological equivalents are Mississippian plants, which are different to the ubiquitous ferns and pteridosperms of the Pennsylvanian. The marked worldwide climatic change which operated at the end of the Mississippian led to a substantial expansion of humid coal-forming environments in Pennsylvanian times, particularly in the palaeoequatorial belt. This favoured the widespread presence of plants living in humid alluvial plain environments. Inevitably, this translates into a collecting bias. The fact that a major proportion of Pennsylvanian plant remains are derived from coal workings, reinforces this bias. The marked differences in the composition of Mississippian and Pennsylvanian floras of the palaeoequatorial belt (Amerosinian Realm of Havlena, 1970) can be explained to a large extent by these environmental considerations. Indeed, plants that are comparable to those found commonly in the Mississippian do occur but rarely in the Pennsylvanian. These include Rhacopteris, Rhacopteridium, Rhodeites, Adiantites, Pseudadiantites, Palaeopteridium, Noeggerathia, etc. Havlena (1970) mentioned these elements as extrabasinal, meaning that they lived on the higher ground, with better drained soils. This concept was further explained by Pfefferkorn (1980). It has been suggested by J.H. Calder (pers. comm.) that "extramire" might be a better designation, since any upstanding area within the basin, and not exclusively the basin margins, could harbour these elements.

It is noted that Adiantites, Pseudadiantites and Rhacopteridium apparently show a pseudopinnate foliar structure, as against the fully planated fronds of ferns and pteridosperms. This kind of structure is commonly associated with the progymnosperms (Archaeopteris), but 
is also found in Rhacopteris (Anisopteris), Triphyllopteris and Genselia, as well as in certain ubiquitous Pennsylvanian Gondwana forms such as Botrychiopsis and Fedekurtzia, which possess different reproductive structures. It is no coincidence that Pseudadiantites rhomboideus and Rhacopteridium speciosum have been recorded in the first instance from the Central Bohemian area where extrabasinal elements are relatively common at certain localities, the inference being that the proximity of upstanding relief at the basin margins would play a role. This refers to the Radnice unit of mid-Westphalian age, which was deposited in an intramontane setting with a strictly limited area of sedimentation flanked by a palaeotopography (Pešek, 1994). A marked contrast exists with the so-called Paralic Coal Belt extending from Alabama to Poland, and bordering a stable, periodically inundated cratonic area from the American Midcontinent to the Russian Platform via Scandinavia. Widespread coal-measure environments developed in this setting. Only assiduous collecting from the Paralic Coal Belt of Pennsylvanian times (almost exclusively Namurian and Westphalian in the absence of most of the Stephanian) has turned up occasional Adiantites, Pseudadiantites, Palaeopteridium and Rhacopteris.

In terms of flora linked to palaeotopography, the work by Leary and Pfefferkorn (1977) and subsequent papers (e.g. Leary 1981), recording plants from a palaeovalley in the lower Pennsylvanian of Illinois, is extremely important. These authors mentioned Palaeopteridium reussii (a probable Noeggerathialean), Megalopteris, and Lesleya as floral elements linked to the drier, better drained environments. Another example from a restricted basinal setting is the record of Rhacopteris bipinnata, Rhacopteris elegans, Rhodeites gutbieri, Palaeopteridium reussii, Palaeopteridium michiganense, and Pseudadiantites sessilis from mainly Duckmantian strata in the small intramontane, strike-slip controlled basin of Peñarroya in the province of Córdoba, SW Spain (Álvarez-Vázquez, 1995, Wagner, 1999). Although these finds are rare, the record is quite varied, which is in agreement with the known palaeogeography and narrow width of the basin (approximately $2-3 \mathrm{~km}$ across originally).

Adiantites adiantoides (Lindley and Hutton) Kidston, Pseudadiantites sessilis (Roehl) Gothan, Ps. rhomboideus (Ettingshausen) comb. nov., and Rhacopteridium speciosum (Ettingshausen) Hirmer, described in the present paper, are joined by Megalopteris sp., and probably also Neuropteris osmundae Lindley and Hutton (recorded as Neurocardiopteris barlovii Bell by Bell, 1944), as putative extrabasinal elements in the lower Pennsylvanian floras of Nova Scotia. Additionally, one should consider Rhacopteris busseana Stur, as recorded by Stopes (1914) from New Brunswick. Although this is not a large number of species, the presence of Pseudadiantites in several localities is a pointer towards the incorporation of extraneous floral elements in the assemblages recovered from alluvial plain sediments, and an indication of nearby areas of higher ground from which these elements were presumably washed in. This may be significant when it comes to interpreting the nature and size of Carboniferous basins in Nova Scotia. Attention is drawn to the fact that a specimen of Rhacopteridium speciosum has been found in the same locality (854) that also yielded Pseudadiantites sessilis.

\section{ACKNOWLEDGEMENTS}

The Geological Survey of Canada is thanked for funding this study. John Utting and Jean Dougherty, of the G.S.C., are thanked for organising the investigation, for making Bell's material available for reexamination, resolving certain locality details, and useful discussion overall. John Calder, Nova Scotia Department of Natural Resources, Halifax, explained the stratigraphic setting of localities, and provided useful discussion. The author is indebted to the referees, S. Archangelsky and J.-P. Laveine for their acute observations which have allowed improving the original manuscript.

\section{REFERENCES}

Álvarez-Vázquez, C. 1995. Macroflora del Westfaliense inferior de la cuenca de Peñarroya-Belmez-Espiel (Córdoba). Tesis Doctoral Universidad Oviedo, 393 pp., 100 láms., Anexos (unpublished).

Anisimova, O.I. 1979. Flora i fitostratigrafiya svednego karbona severnogo kavkaza (Flora and phytostratigraphy of the Middle Carboniferous of North Caucasus). Akademia Nauk Ukrainskoy SSR. Institut Geologicheskikh Nauk. Kiev, "Naukova Dumka”, 100 pp., 47 Tab.

Bell, W.A. 1940. The Pictou Coalfield, Nova Scotia. Canada Department of Mines and Resources, Geological Survey, Memoir 225, 141 pp., 10 pls.

Bell, W.A. 1944. Carboniferous rocks and fossil floras of northern Nova Scotia. Canada Department of Mines and Resources, Geological Survey, Memoir 238, 120 pp., 79 pls.

Bell, W.A. 1966. Illustrations of Canadian Fossils. Carboniferous plants of eastern Canada. Geological Survey of Canada, Paper 66 (11), 76 pp.

Belt, E.S. 1964. Revision of Nova Scotia Middle Carboniferous units. American Journal of Science, 262, 653-673.

Boureau, E. 1975. Traité de Paléobotanique. IV (2), 768 pp.

Brousmiche, C. 1983. Les Fougères sphenoptéridiennes du Bassin Houiller Sarro-Lorrain (Systématique Stratigraphie). Société Géologique du Nord, Publication 10, 480 pp., 100 pls.

Calder, J.H. 1998. The Carboniferous evolution of Nova Scotia. In: Lyell: the Past is the Key to the Present (Eds. D.J. Blundell and A.C. Scott). Geological Society, London, Special Publications, 143, 261-302.

Daber, R. 1959. Die Mittel-Visé-Flora der Tiefbohrungen von Doberlug-Kirchhain. Geologie, Beiheft 26, 83 pp., 17 Tafn.

Dawson, J.W. 1860. On an Undescribed Fossil Fern from the Lower Coal-Measures of Nova Scotia. Quarterly 
Journal Geological Society of London, 17, 5.

Dawson, J.W. 1861. On the Pre-carboniferous Flora of New Brunswick, Maine, and Eastern Canada. The Canadian Naturalist and Geologist, 6 (3), 161-180.

Dawson, J.W. 1862. On the Flora of the Devonian Period in North-Eastern America. Quarterly Journal Geological Society of London, 18, 296-330, pls. 12-17.

Dawson, J.W. 1871. The Fossil Plants of the Devonian and Upper Silurian Formations of Canada. Geological Survey of Canada, 92 pp., supplementary section 8 pp., 20 pls.

Dawson, J.W. 1873. Fossil Plants of Lower Carboniferous and Millstone Grit Formation of Canada. Report Geological Survey of Canada, 47 pp., 10 pls.

Dawson, J.W. 1882. The Fossil Plants of the Erian (Devonian) and Upper Silurian Formations of Canada, Part II. Geological Survey of Canada, 95-142, pls. 21-24.

Ettingshausen, C. von 1852. Die Steinkohlenflora von Stradonitz in Böhmen. Abhandlungen k. k. geologischen Reichsanstalt, 1 (3), 4, 13 pp., 6 Tafn.

Ettingshausen, C. von 1854. Die Steinkohlenflora von Radnitz in Böhmen. Abhandlungen k. k. geologischen Reichsanstalt, 2 (3), 74 pp., 29 Tafn.

Fiebig, H.E.R. 1957. Bemerkenswerte Beobachtungen bei der Aufnahme des neuen Richtschichtenschnittes der Bochumer (Fettkohlen-) Schichten auf der Zeche Ver. Bonifacius. Mitteilungen der Westfälischen Berggewerkschaftskasse (Kukuk-Festschrift), 12, 13-25, 3 Tafn.

Göppert, H.R. 1836. Die fossilen Farrnkräuter (Systema filicum fossilium). Verhandlungen der Kaiserlichen Leopoldinisch-Carolinischen Akademie der Naturforscher (Novorum Actorum Academiae Caesareae Leopoldino-Carolinae Naturae Curiosorum), 17 (Supplement), 486 pp., 44 Tafn.

Gothan, W. 1929. Die Steinkohlenflora der westlichen paralischen Carbonreviere Deutschlands. Arbeiten Institut für Paläobotanik und Petrographie der Brennsteine, 1 (1), 1-48, Tafn. 1-16.

Gothan, W. 1953. Die Steinkohlenflora der westlichen paralischen Steinkohlenreviere Deutschlands. Geologisches Jahrbuch, Beiheft 10, 83 pp., 44 Tafn.

Gothan, W. 1954. Pflanzengeographisches aus dem mitteleuropäischen Karbon. Geologie, 3, 219-257.

Gothan, W. und Remy, W. 1957. Steinkohlenpflanzen. Leitfaden zum Bestimmen der wichtigsten pflanzlichen Fossilien des Paläozoikums im rheinisch-westfälischen Steinkohlengebiet. Verlag Glückauf, Essen, 248 pp., 6 Tafn.

Havlena, V. 1970. Einige Bemerkungen zur Phytogeographie und Geobotanik des Karbons und Perms. Compte Rendu 6 Congrès International de Stratigraphie et Géologie du Carbonifère, Sheffield 1967, 3, 901-912.

Hirmer, M. und Guthörl, P. 1940. Die Karbon-Flora des Saargebietes. 3. Filicales und Verwandte. 1. Noeggerathiineae. 2. Rhacopteris. Palaeontographica, Abt. B, Supplement-Band 9 (3), 60 pp., 13 Tafn.

Hofmann, A. und Ryba, F. 1899. Leitpflanzen der palaeozoischen Steinkohlenablagerungen in MittelEuropa. Prag. 20 Tafn.

Jongmans, W.J. 1928. Stratigraphie van het Karboon in het algemeen en van Limburg in het bijzonder. Jaarboek Mijnbouwkundige Vereeniging Delft 1926-1927, 50 pp., 17 pls. (Mededeeling No6 Geologisch Bureau Heerlen.)

Josten, K.-H. 1962. Die wichtigsten Pflanzen-Fossilien des Ruhrkarbons und ihre Bedeutung für die Gliederung des Westfals. Fortschritte Geologie Nordrhein-Westfalen, 3, 753-772, 4 Tafn.

Josten, K.-H. 1983. Die fossilen Floren im Namur des Ruhrkarbons. Fortschritte Geologie Rheinland und Westfalen, 31, 327 pp.

Josten, K.-H. 1991. Die Steinkohlen-Floren Nordwestdeutschlands. Fortschritte Geologie Rheinland und Westfalen, 36, 434 pp., 220 Tafn.

Kidston, R. 1886. Catalogue of the Palaeozoic Plants in the Department of Geology and Palaeontology, British Museum (Natural History). London B.M.N.H., 288 pp.

Kidston, R. 1923. Fossil Plants of the Carboniferous Rocks of Great Britain (first section). Memoirs Geological Survey of Great Britain. Palaeontology, 2 (1, 2), 1-197, pls. 1-47.

Kidston, R. 1924. Fossil Plants of the Carboniferous Rocks of Great Britain. Memoirs Geological Survey of Great Britain, Palaeontology, 2 (5), 379-522, pls. 92-122.

Knaus, M.J. 1994. Triphyllopteris collombiana: A clarification of the generic concept based on rediscovered specimens from Kossberg bei Plauen, Germany, and a reassignment of the North American species of Triphyllopteris to Genselia gen. nov. International Journal of Plant Sciences, 155, 97-116.

Knaus, M.J., Upchurch, G.R. and Gillespie, W.H. 2000. Charbeckia macrophylla gen. et. sp. nov. from the Lower Mississippian Price (Pocono) Formation of southeastern West Virginia. Review Palaeobotany \& Palynology, 3, 71-92.

Laveine, J.-P. 1967. Contribution à l'étude de la flore du Terrain Houiller. Les Neuroptéridées du Nord de la France. Études géologiques pour l'Atlas de Topographie souterraine, Service Géologique Houillères du Bassin du Nord et du Pas-de-Calais. I.- Flore fossile, 5. Texte: 344 pp., pls A-H, J-K, M-P; Atlas: 84 pls.

Leary, R. 1974. Two Early Pennsylvanian floras of western Illinois. Transaction Illinois State Academy of Sciences, 67, 430-440.

Leary, R. 1981. Early Pennsylvanian Geology and Paleobotany of the Rock Island County, Illinois, Area. Part 1: Geology. Illinois State Museum, Reports of Investigations, 37, $88 \mathrm{pp}$.

Leary, R. and Pfefferkorn, H.W. 1977. An Early Pennsylvanian Flora with Megalopteris and Noeggerathiales from West-Central Illinois. Illinois State Geological Survey, Circular 500, 77 pp.

Leggewie, W. 1966. Zur Morphologie und Systematik einiger Karbonpflanzen. Über Palaeopteridium sessilis (Potonié 1896). Fortschritte Geologie Rheinland Westfalen, 13 (1), 297-302, 4 Tafn.

Lesquereux, L. 1858. Fossil Plants of the Coal Strata of Pennsylvania. In: Rogers, H.D. The Geology of Pennsylvania. II (pt. II), 835-884, 23 pls.

Lesquereux, L. 1879-80. Description of the Coal Flora of the Carboniferous Formation in Pennsylvania and 
throughout the United States. Vols I-II. Second Geological Survey of Pennsylvania: Report of Progress, P: 694 pp. (Text 1880), 85 pls. (Atlas 1879).

Lindley, J. and Hutton, W. 1831-37. The Fossil Flora of Great Britain; or, Figures and Descriptions of the Vegetable Remains Found in a Fossil State in this Country. London, Ridgway \& Sons, I, 218 pp., pls. 1-79 (1831-33); II, 206 pp., pls. 80-156 (1833-35); III, 204 pp., pls. $157-230$ (1837).

Matthew, G.F. 1906. A Review of the Flora of the Little River Group. Transactions Royal Society of Canada, $\left(2^{\text {nd }}\right.$ series), section $I V$, Geological and Mineralogical Sciences, 12, 99-149.

Nĕmejc, F. 1928. A revision of the carboniferous and permian flora of the coal-districts in Central Bohemia. Palaeontographica Bohemiae, 12, 41-82, 10 Tab.

Nĕmejc, F. 1937. On Discinites K. Feistm. Bulletin international Académie des Sciences de Bohême, 7 pp., 1 pl.

Oleksyshyn, J. 1976. Fossil Plants of Pennsylvanian Age from Northwestern Narragansett Basin. Geological Society of America, Memoir 146, 143-180.

Pešek, J. 1994. Carboniferous of Central and Western Bohemia (Czech Republic). Czech Geological Survey, Prague, 61 pp., 3 pls., 26 maps.

Pfefferkorn, H.W. 1980. A note on the term "upland flora". Review Palaeobotany Palynology, 30, 157-158.

Potonié, H. 1893. Ueber einige Carbonfarne. IV. Theil. Jahrbuch der Königlich Preussischen geologischen Landesanstalt und Bergakademie für das Jahr 1892, 13, 1-11, 3 Tafn.

Potonié, H. 1896. Die floristische Gliederung des deutschen Carbon und Perm. Abhandlungen der Königlich Preussischen geologischen Landesanstalt, (N.F.), 21, 58 pp.

Potonié, H. 1921. Lehrbuch der Paläobotanik (Zweite Auflage umgearbeitet von W. Gothan). Verlag Gebrüder Borntraeger, Berlin, 537 pp.

Rabitz, A. 1957. Flözgleichstellung in den Essener Schichten nördlich Bochum und Dortmund. Geologisches Jahrbuch, 73, 389-456, Tafn. 15-17.

Remy, W. und Remy, R. 1959. Pflanzenfossilien. Ein Führer durch die Flora des limnisch entwickelten Paläozoikums. Akademie-Verlag, Berlin, 285 pp., Tafn. 1-3.
Remy, W. und Remy, R. 1977. Die Floren des Erdaltertums. Einführung in Morphologie, Anatomie, Geobotanik und Biostratigraphie der Pflanzen des Paläophytikums. Verlag Glückauf GMBH, Essen, 467 pp.

Roehl, E. von 1868. Fossile Flora der SteinkohlenFormation Westphalens einschliesslich Piesberg bei Osnabrück. Palaeontographica, 18, 192 pp., 32 Tafn.

Schimper, W.P. 1869. Traité de Paléontologie végétale ou la flore $d u$ monde primitif dans ses rapports avec les formations géologiques et la flore du monde actuel. I, Paris, Ballière et fils, 738 pp., 110 pls. (Atlas 1874).

Stockmans, F. et Willière, Y. 1952-53. Végétaux namuriens de la Belgique. Association Étude Paléontologie et Stratigraphie houillères, Publication 13, 382 pp. (Texte 1953), 57 pls. (Atlas 1952).

Stockmans, F. et Willière, Y. 1954. Flores namuriennes de la Belgique. Incertitudes et hypothèses de travail. Volume jubilaire Victor van Straelen, I, 117-132, pls. 1-3.

Stopes, M.C. 1914. The "Fern Ledges" Carboniferous Flora of St. John, New Brunswick. Canada Department of Mines, Geological Survey, Memoir 41, 142 pp., 25 pls.

Stur, D. 1875-77. Die Culm-Flora der Ostrauer und Waldenburger Schichten. Abhandlungen der KaiserlichKöniglichen Geologischen Reichsanstalt, 8, 366 pp., Tafn I (XVIII)-XXVII (XLIV).

Stur, D. 1885. Beiträge zur Kenntniss der Flora der Vorwelt. II. Die Carbon-Flora der Schatzlarer Schichten. I: Die Farne der Carbon-Flora der Schatzlarer Schichten. Abhandlungen der Kaiserlich-Königlichen Geologischen Reichsanstalt, 11 (1), 418 pp., Tafn XVIII-XXV, XXVb, XXVI-LXV.

Trapl, S. 1926. Př́ručka fytopalaeontologie. Matice hornicko-hutnické v Praze, I (1925) (1), 163 pp., 7 Tab.

Wagner, R.H. 1999. Peñarroya, a strike-slip controlled basin of early Westphalian age in Southwest Spain. Bulletin Czech Geological Survey, 74 (2), 87-108.

Wagner, R.H., Coquel, R. and Broutin, J. 1983. Mississippian floras of the Sierra Morena, S.W. Spain. In: Contributions to the Carboniferous Geology and Palaeontology of the Iberian Peninsula (Ed. M.J. Lemos de Sousa). Universidade do Porto, Faculdade de Ciências, Mineralogia e Geologia, 101-126.

White, D. 1905. The Seeds of Aneimites. Smithsonian Miscellaneous Collections, 47, 322-331, pls. 47-48.

Manuscrito recibido: 30 de mayo, 2000 Manuscrito aceptado: 6 de febrero, 2001 